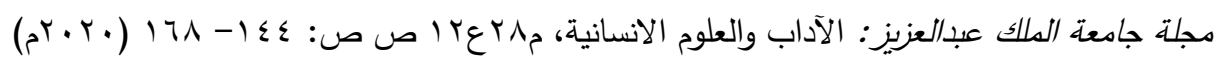
DOI:10.4197/Art.28-12.6

\title{
الوقف العلمي رافد لا ينضب لمحات فقهية تطبيقية دراسة تأسيسية مقدمة للجامعات السعودية والمؤسسات العلمية
}

\author{
د. سعود بن فرحان محمد الــــبْـلاني العنزي

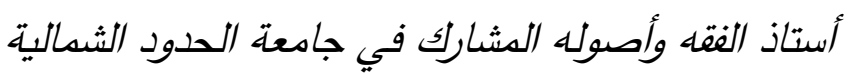 \\ رئيس قسم الدراسات الإسلامية في \\ كلية التربية والآداب
}

مستخلص . يتحدث البحث عن مورد مالي من أصول ثابتة للجامعات وكافة المؤسسات العلمية، وعنونته بـــا

(الوقف العلمي رافد لا ينضب - لمحات فقهية تطبيقية)

حيث سارت معظم الجامعات العالمية على هذه الموارد مما جعلها لا تحتاج إلى تمويل دوري من ميزانية الدولة

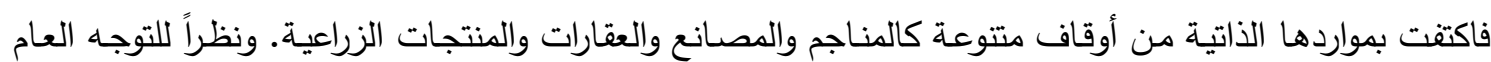

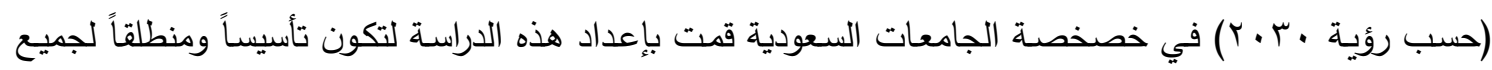

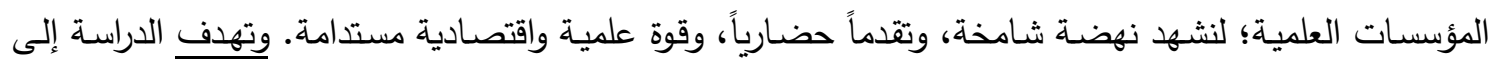
تعريف الوقف، ومشروعيته، وأهمية الوقف في البناء الحضاري، وجهود علماء الأمة في بيان أحكام الوقف، وأهمية

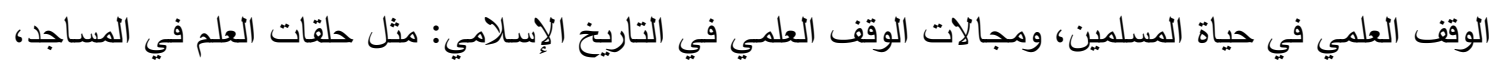

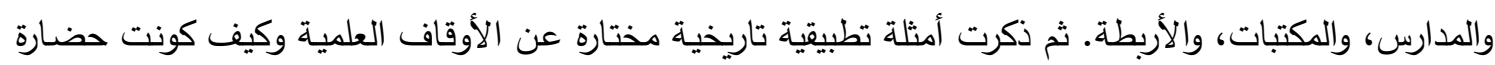

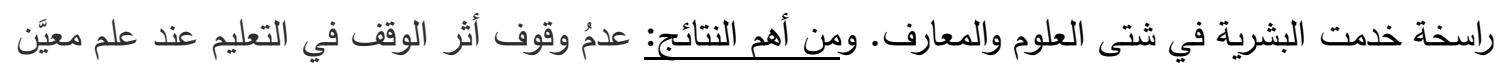
بحد ذاته؛ وإنما شمل كل موضوعات المعرفة البشرية تستوي في ذلك العلوم الثيات الثرعية والعلوم البحتة والتطبيقية

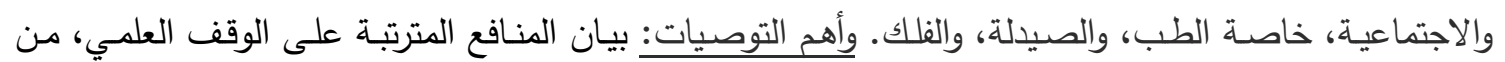

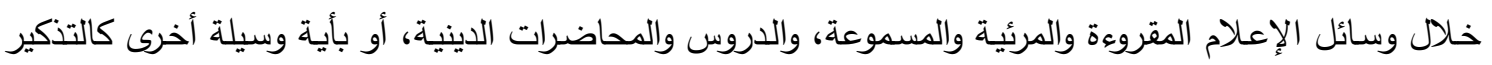
بالآيات القرآنية والأحاديث النبوية التي تحث على عمل الخير والإنفاق على طلبة العلم والمؤسسات التعليمية، واستصدار فتاوى شرعية من كبار العلماء بجواز الوقف على المؤسسات التعليمية من جامعات وغيرها. الكلمات المفتاحية: الوقف - التبرع - التسبيل - موارد - الجامعات - مراكز علمية. 


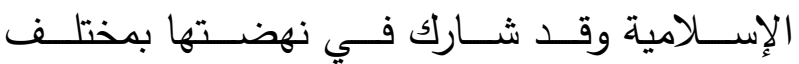
المجالات.وقد اخترت الكتابة "الوقف العلمي رافٌْ لا نالِ ينضب" وذلك تمشياً مـع توجها الدولـة المباركـة في لوني

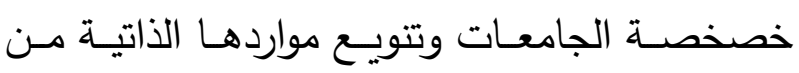
أوقاف علميـة واستتثمارات متعددة ممـا يـدعم التقدم العلمي والبحثي وخدمة المجتمع ومما ينسجم مع بنود

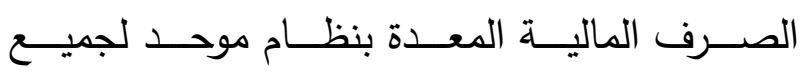

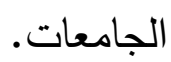
ثانياً: أهداف البحث: '_ بيـان مشروعية الوقف العلمي وعلاقته بالوقف لهابـ

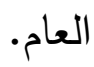
r _ إبراز أهمية الوقف في البناء الحضاري. بـ ذكر جهود علماء الأمة في بيان أحكام الوقف. ع_ بيان أهمية الوقف العلمي في حياة المسلمين. ○_ مجالات الوقف العلمي في التاريخ الإسلامي:

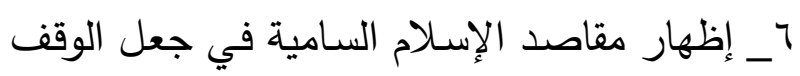
العلمي رافد لا ينضب. ثالثاً: مشكلة البحث وتساؤلاته: هنـاك تسـاؤلات كثيـرة حـول رأي الفقهـاء في حكم توجيـه الوقف وجعل موارده خاصـة للتعليم وللمراكز البحثية، وكذلك جعل جزء من ميزانية الجامعة في

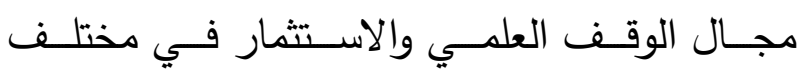

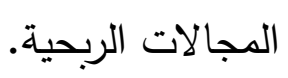
فيكـون التسـاؤل: مـا مجـالات الوقفـ العلمسي على التى الجامعات ودور العلم والمراكز البحثية؟

\section{المقدمة}

إن الحمد الله نحمده ونستعينه ونستغفره، ونعوذ بالله من شرور أنفسنا، ومن سيئات أعمالنا، من يهده الله

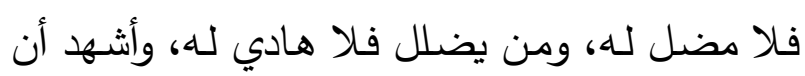
لا إلـه إلا الله وحده لا شـريك لـه، وأشـهـ أن محمداً عبده ورسوله. أما بعد:

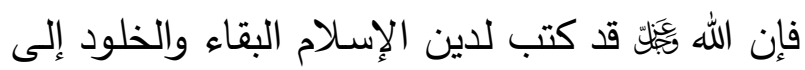

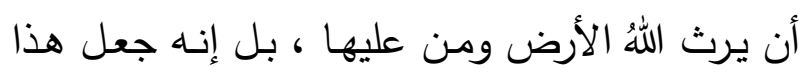

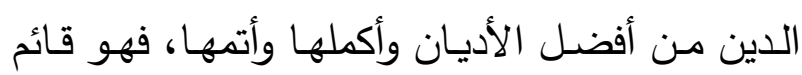

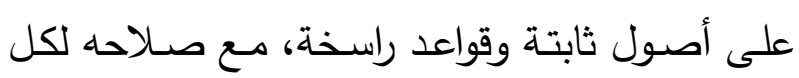

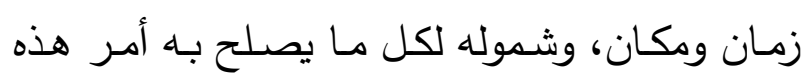
الأمة في دينها ودنياها.

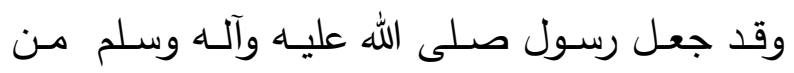

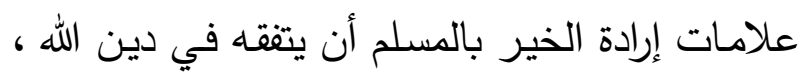

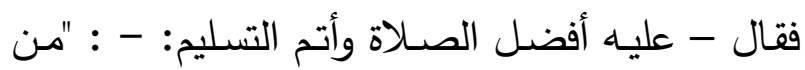
يرد الله بـه خيراً يفقهه في الدين". (') وقد تكفل الله

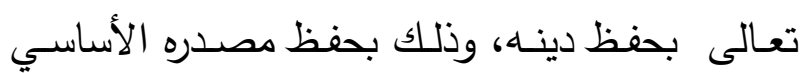
المتمثل في القرآن الكريم والسنة النبوية المطهرة. أهمية الموضوع وسبب اختياره: لقد كان للوقف الإسلامي -والتفقُّه فيه- وضبط موارده

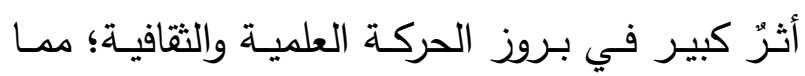

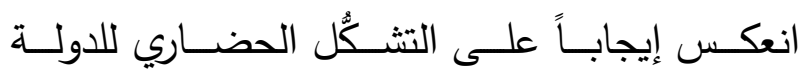

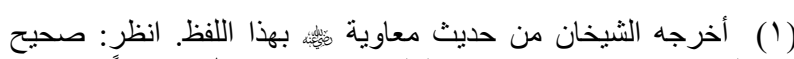

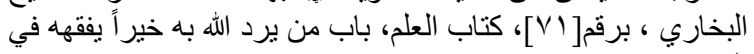

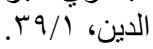




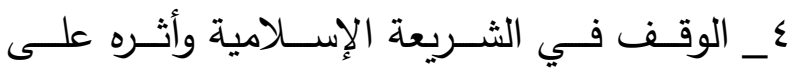

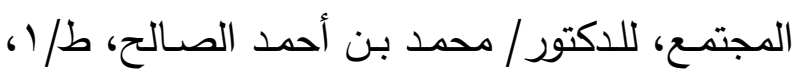
r Y ا اه، فهرسة مكتبة الملك فهد الوطنية، الرياض. سادساً: منهج البحث وإجراء اته: ا- إتباع المنهج الاستقرائي الاستتباطي التحليلي

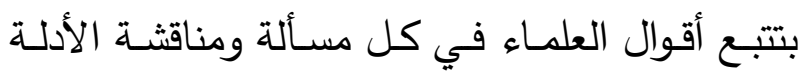
والترجيح، مع ذكر تطبيقات تاريخية. ץ- الرجوع إلى المصـادر الأصلية، ونسبة الأقوال إلى أصحابها. r- كتابـة الآيـات القرآنيـة بالرسم العثـاني وعزوهـا

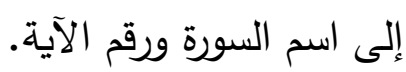
ع- تخريج الأحاديث، وبيان درجة صحتها إذا وجد الد اله في غير صحيح البخاري أو مسلم. 0- شرح المصطلحات الغريبة. 7- وضع فهارس للبحث. سـابعاً: تقسـيمات البحـث: يتكون البحثث مـن مقدمة، وثلاثة مباحث، وخاتمة.

المقدمة: وفيها بيان أهمية الموضوع وسبب وهاحة اختياره، وأهدافـه، و ومشكلته وتسـاؤلاته، وحدوده، والدراسـات السابقة، ومنهج البحث وإجراءاته، وتقسيماته.

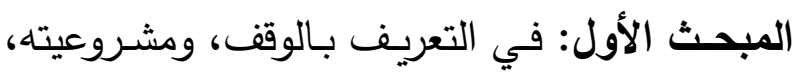
وأهميته في البناء الحضاري. وفيه أربعة مطالب:

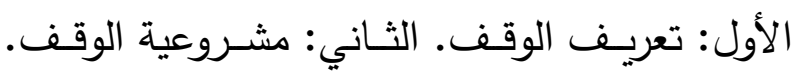
الثالث: أهمية الوقف في البناء الحضاري. المطلب الرابع: جهود الفقهاء في بيان أحكام الوقف.
رابعاً: حدود البحث: سيكون البحث مقتصراً على المذاهب الفقهية الأربعة

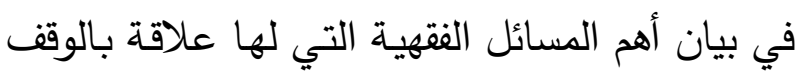

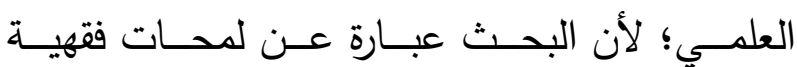
تطبيقية. خامساً: الاراسات السابقة: لـم أجد مـن بحث هذا الموضـوع بهذا العنوان(بعد

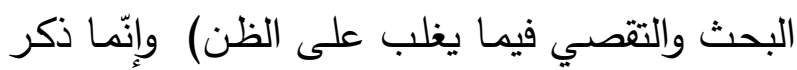

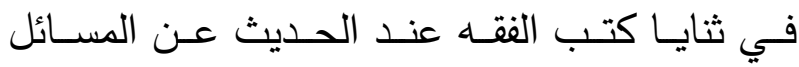
المتعلقة بالوقف على وجه العموم،

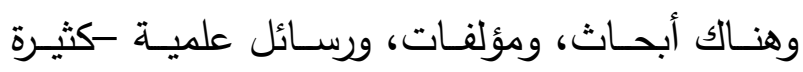

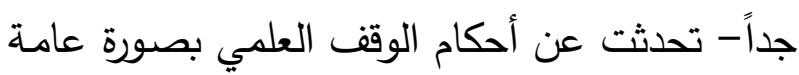
دون تخصيصـه وذكر التطبيقات التاريخيـة وربطها بمسائل الوقف؛ مثل: لا على سبيل الحصر :

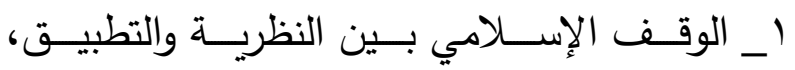

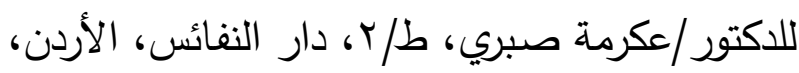
.$p^{2} \cdot 11$ Y _ أثر الوقف على الدعوة إلى الله تعالى، لخالد بن

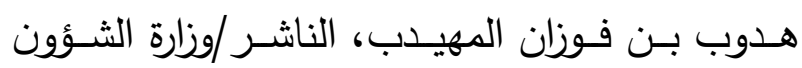
الإنسـلامية والأوقـاف والــــوة والإرشـاد، السـعودية، . $) \leqslant Y\}$ بـ مجـالات الوقـف الــؤثرة في الـــعوة إلـى الله، للاكتور/مقتدى حسن ياسين، ط/ ال ، مؤتمر الأوقاف

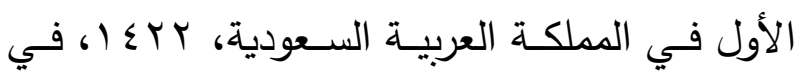

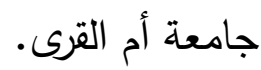


الوقف في اللغة: أصل يدل على تمكث في الثيء، مصـدر وقـف(').ومـن معـاني الوقـف فـي اللغــة: الحبس، والمنع، والسكون، والسكوت، والإدامة(؟).

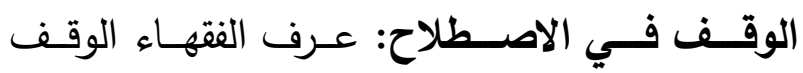
بتعريفـات متعـددة وفـق اتجاهـات مختلفـة،لا داعي للإسـهاب في ذكرها؛ لأنـه لا يكاد يخلو كتاب فقهي من النص عليها، والاختلاف في تعريفه مبني على اختلاف الفقهاء في بعض أحكام الوقف والتقريعات الجزئية.

ففي المـذهب الحنفـي هو: حبس العين على حكم مُلك الله والتصدق بالمنفعة (). وفي المذهب المـالكي هو: جعل منفعة مملوك ولو بـأجرة، أو غلقــه لمسـتحقه بصـيغة مــدة مــا يـراه

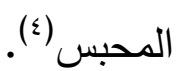
وفي المــذب الثــافعي هـو : تحبـيس مـال يمكن الانتفـاع بـه مـع بقـاء عينــ؛ بقطـع تصـرف الواقف وغيره في رقبته، ويصرف في جهة خير تقرباً إلى الله تعالى (0). وفي المـذهب الحنبلي هو:تحبيس الأصل وتسبيل المنفعة(7).وهو من أخصر تلك التعريفات وأوضحها. وهذا التعريف مستمد من حديث (إن شئت حبسـت أصلها وتصدقت بالمنفعة)(') ومن هذا تتفرع الآراء

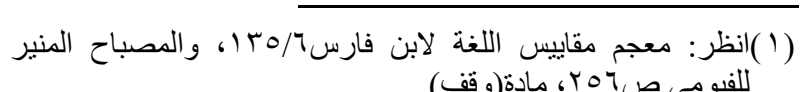

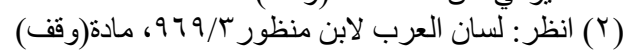

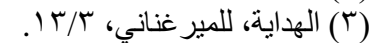

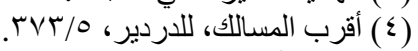

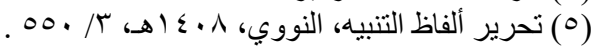

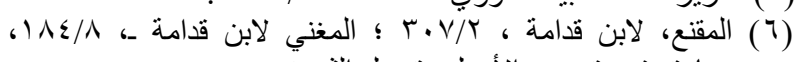
و عبارته فيه: تحبيس الأصل وتسبيل الثمرة.
المبحـث الثـاني: أهميــة الوقفـ العلمي في حيـاة المسلمين. وفيه مطلبان: المطلب الأول: منع بيع الوقف.

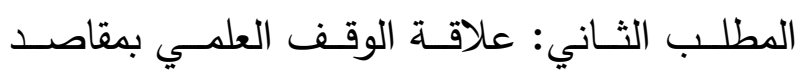
الشريعة.

المبحث الثالث: مجلات الوقف العلمي وتطبيقاته في التاريخ الإسلامي. وفيه مطلبان: المطلب الأول: مجالات الوقف العلمي في التاريخ الإسلامي: - إن مثـل: حلقـات العلــم فــي المســاجد، والمــــارس، والمكتبات، والأربطة.... المطلب الثـاني: الأمثلــة التطبيقيـة التاريخيـة على ولى الأوقاف العلمية. الخاتمةة: وفيها أهم النتائج والتوصيات. فهرس المصادر . المبحث الأول

في التعريف بالوقف، ومشروعيته، وأهميته في البناء الحضاري. وفيه ثلاثة مطالب: المطلب الأول: تعريف الوقف في اللغة وفي اصطلاح الفقهاء. المطلب الثاني: مشروعية الوقف. المطلب الثالث: أهمية الوقف العلمي في البناء الحضاري. المطلب الأول: تعريف الوقف. 


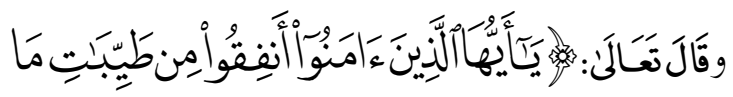

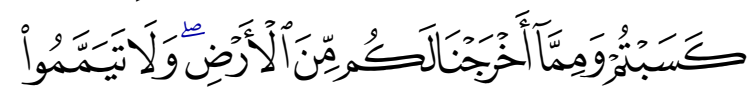

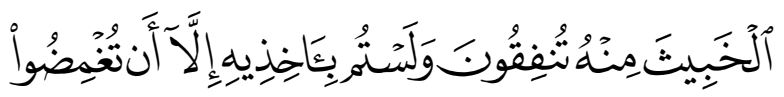

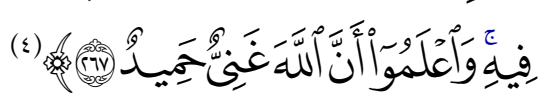
r - السنة النبويـة :جاء في كتب السنة أحاديثُ متعددة تدل على مشروعية الوقف، منها: أولاً: عن أبـي هريـرة رضـي الله عنـه أن النبـي -

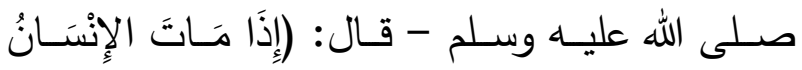

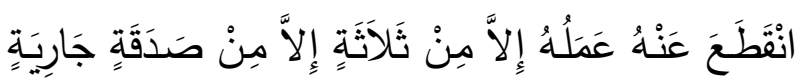

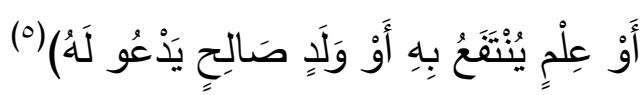
قال النووي في شرحه على صسيح مسلم : "وفيـ دليل لصحة أصل الوقف وعظيم ثوابه وبيان فضيلة العلم والحث على الاستكثار منه والترغيب في توريثه بالتعليم والتصنيف والإيضاح"(†) ثانياً: عن أبي هريرة رضي الله عنه أن النبي صلى الله عليـه وسـلم - قال: إن ممـا يلحق المؤمن مسن عمله وحسـناته بعد موتهـ: علمـاً علمـه ونشـره، وولداً صسالحاً تركه، ومصحفاً ورثه، أو مسجداً بنـاه، أو بيتاً لابـن السبيل بنـاه، أو نهـراً أجراه، أو صـدقةً

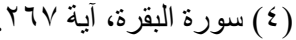

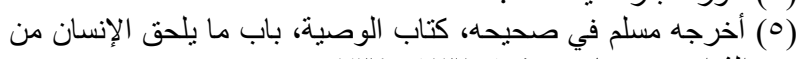

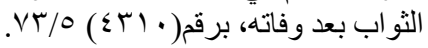

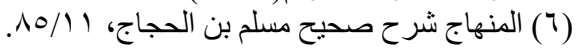

الفقهية في مسائل الوقف؛ من حيث اللزوم والتوقيت والتأبيد وغير ذلك. ملحوظتان: '_ الاختلاف في تعريـف الوقف اصطلاحاً مبني على الاختلاف في حكمه وبعض شروطه: فبعضهم يرى أن الوقف لازم، وآخرون يرون أنه غير لازم ، وبعضهم يشترط فيه معنى القربـة، وآخرون لا يرون ذلك شرطاً(r). بـ يــدخل الوقـف العلمـي فـي جميــع التعريفـات السـابقة؛ وذلك حسب تحديد الجهـة الموقوف عليها مـن قبـل الواقـف؛ كالمـدارس والجامعـات والمراكـز البحثية وأي مؤسسة علمية. المطلب الثاني: مشروعية الوقف. الوقفـ مشـروع بـالوحيينن، وقد تضـافرت النصـوص على مشـروعيته والحث عليـه،ودل على مشـروعيته كل sن: 1- القرآن الكريم: ورد في كتاب الله تعالى نصوص تحـث وتـدفع أتباعـهـ علـى البــل والإنفــاق وفعـل الخيـرات . والوقف إلاّ جزء مـن أعمـال البر وفعـل

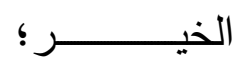

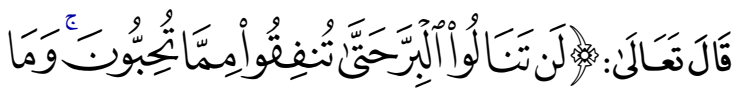

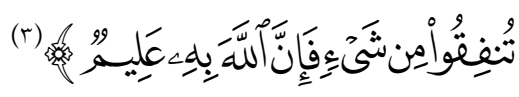

(1) (أخرجه البخاري، كتاب الثروط، باب الثروط في الوقف، برقم (YVTV)

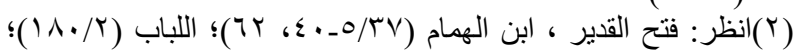

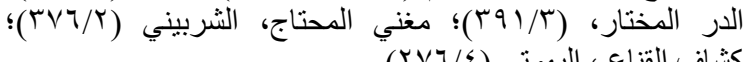

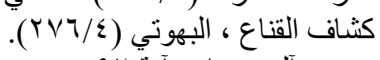

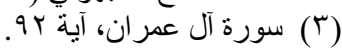


تأمرني به؟ قال:(إن شئت حبَّست أصلها، وتصدقت بهـا) قـال: فتصــدق بهـا عمـر : أنـهـه لا يبــاع ، ولا يوهـب، ولا يـورث، وتصـدق بهـا في الفقـراء، وفي القربى، وفي الرقاب، وفي سبيل الله، وابن السبيل، والضـيف،لا جنـاح على مسن وليهـا أن يأكل منهـا بالمعروف، ويطعم غير متمول.(؟)

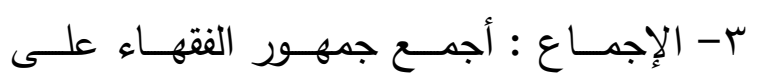
مشروعيته (*)، وأثبت ذلك الإمسام الترمذي"(؟) ورُوي عن القرطبي: "رادّ الوقف مخالفت للإجماع فلا يلتقت إليه"(v)

وكثير من أحكام الوقف ثابتة بالاجتهاد؛ نظرا لأن

النصوص الواردة فيـه في جملتها عامـة الدلالة، ممـا دعـا العلمـاء إلى بـذل الجهــ في تفصـيل أحكامـهـ وبيانها، ويعد هذا العموم ميزة توسـع مجالات الوقف وتواكب النوازل ومتغيرات الزمان. المطلب الثالث: أهمية الوقف في البناء الحضاري.

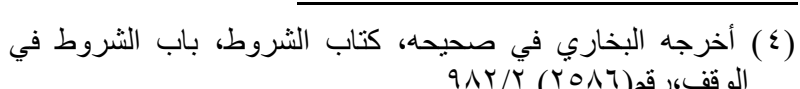

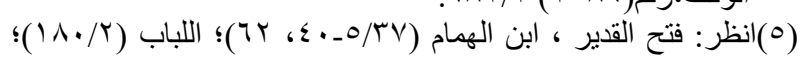

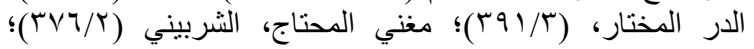

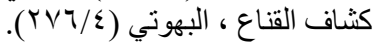

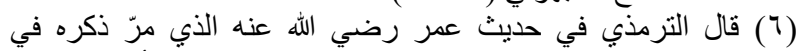

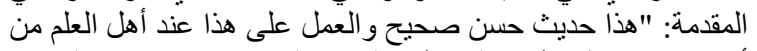

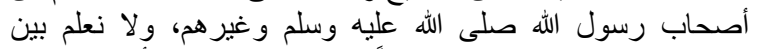

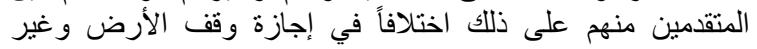

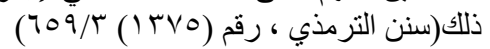

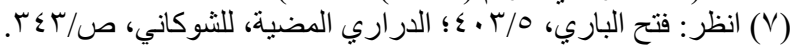

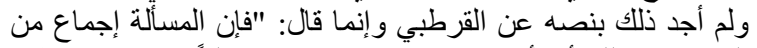

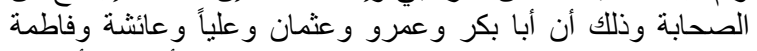

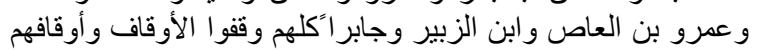

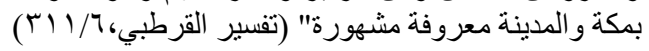

أخرجها من ماله في صـحته وحياته تلحقه من بعد موته)( (1) ثالثاً:عن أبـي هريـرة رضـي الله عنـه أن النبـي صلى الله عليه وسلم - قال: (من احتبس فرساً في سبيل الله إيمانا بالله وتصديقاً بوعده، فإن شبعه وريّه (r)(باثه وبوله، في ميزانه يوم القيامة) رابعاً: عن عمر رضي الله عنه: كانت لرسول الله - صــلـى الله عليــه وسـلم - ثـلاثث صــفايا: بنــو النضـير، وخيبر ، وفـدك. فأمسا بنـو النضـير فكانــت حبساً لنوائبه، وأما فدك فكانت حبساً لأبناء السبيل، وأما خيبر فجزأها رسول الله - صلى الله عليه وسلم - ثلاثـة أجـزاء : جـزأين بـين المسـلمين، وجـزء نفقــة لأهلـه، فمـا فضـل عـن نفقـة أهلـهـ جعلـه بـين فقـراء

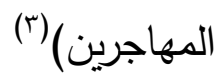
خامسـاً: وعـن عبـدالله بـن عمـر بـن الخطـاب رضي الله عنهما - أن عمر - رضي الله عنه أصساب أرضـاً بخيبر ، فأتى النبي - صلى الله عليه وسلم سيستأمره فيها، فقال يا رسول الله: إني أصبت أرضاً بخيبر لم أُصب مالاً قط أنفس عندي منه، فما

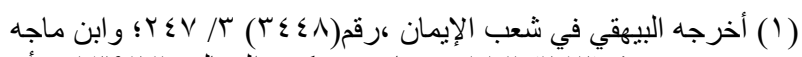

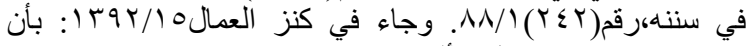

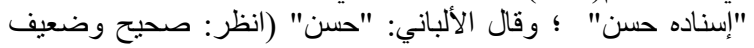

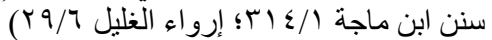

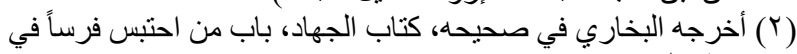

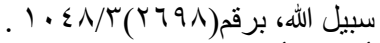

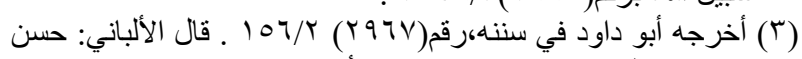

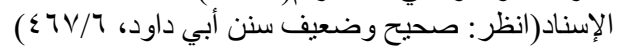


وعلى دفن المـوتى، وختـان الأطفـال، وعلى إعانـة

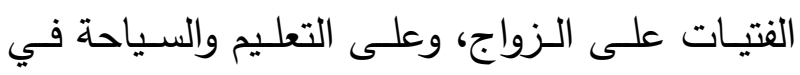

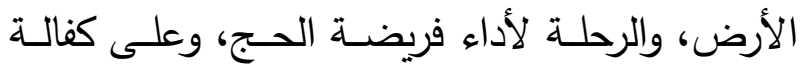

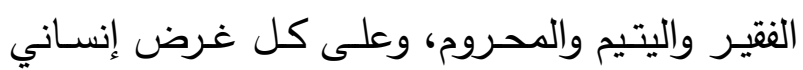

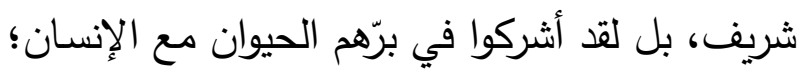

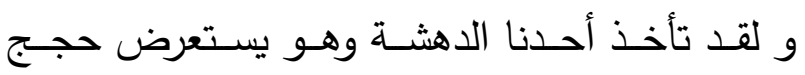
الواقفين ( أهل الوقف ) ليرى القوم في نبل نفوسهم ويقظة ضمائرهم ، وعلوّ إنسانيتهم، بل في سلطان

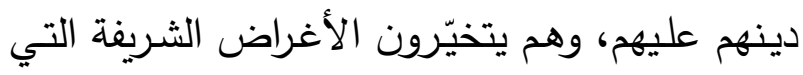
يوقفون لها أمسالهم، و يرجون أن تتفق في سبيل

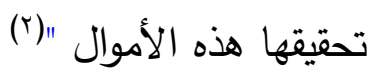
المطلب الرابـع: جهـود الفقهـاء في بيـان أحكـام الوقف. لا يخلو كتاب من كتب الفقهاء المتقدمين والمتأخرين مـن الكـلام عـن الوقـف والتفصـيل فـي مســائله المتتوعـة، ويقـع بيـنهم خـلاف في بعض المسـائل؛ فمثلاً اختلافهم في تعريفه -كما سبق - وهو مبني

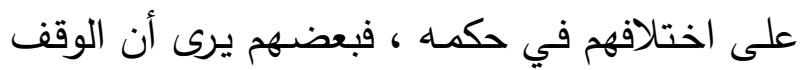

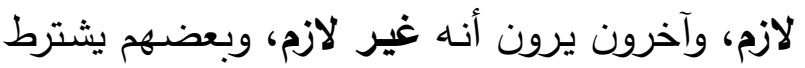

فيه معنى القربة، وآخرون لا يرون ذلك شرطاً ("). وقد بذل الفقهاء جهوداً عظيمة في خدمة هذا التبرع

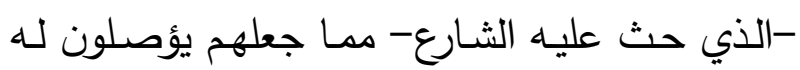
ويقعدون بناء على منهجه في ذلك مما خدم الخلف

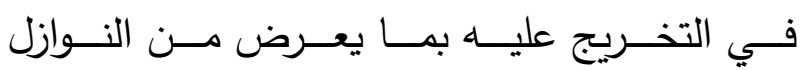

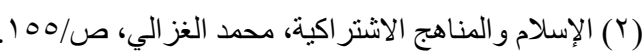

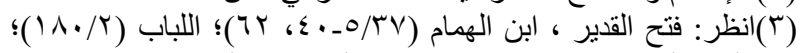

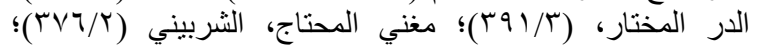

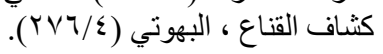

إن الأوقاف لها دور كبير عبر التاريخ في البنـاء

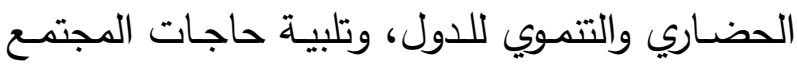

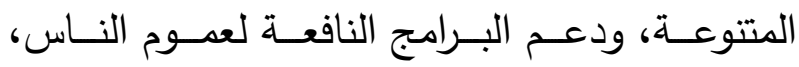

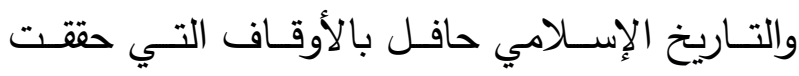

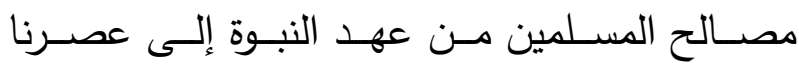
الحاضـر ، يشهـه لذلك الأدلـة والنصـوص في في السـنة النبويـة، والتـاريخ الإســلامي، والســـلات والوثـائق

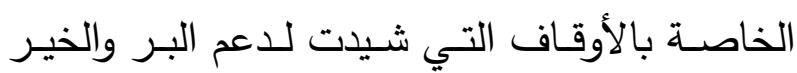

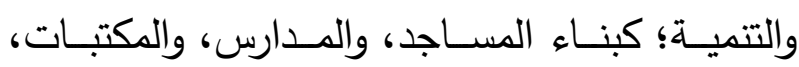

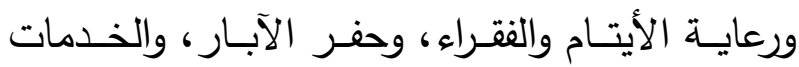
الصحية وغير ذلك. فكان أثر الوقف في التقدم الحضـاري واضـحاً في

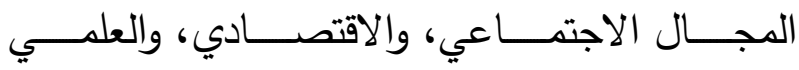
والطبي،والعمراني؛ فقد قامت الأوقاف بتمويل العديد

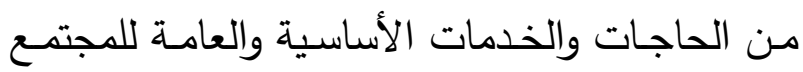
مما يخفف العبء على ميزانيات الدول (').

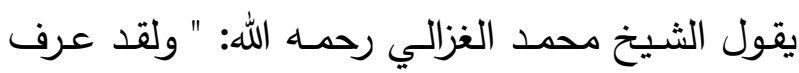

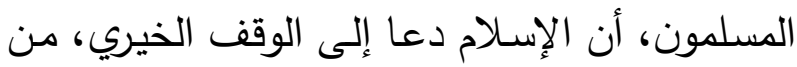
حيث كان دين فطرة، ثم من حيث دعا دعوة ملحة الإنا إلى البر بالناس، وإلى الصدقة الجاريـة في نصوص

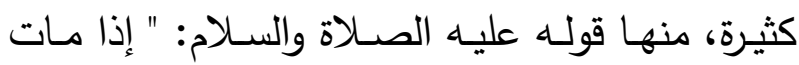
الإنسان انقطع عمله إلا من ثلاث: صدقة جارية، أو

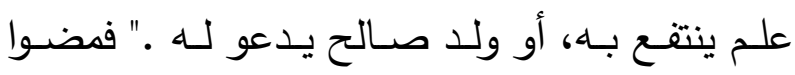

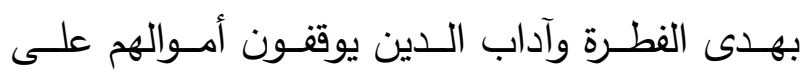

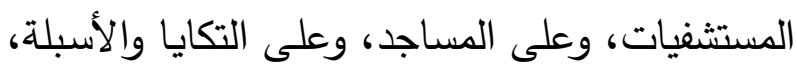

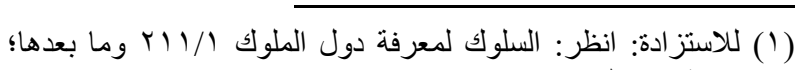
مقدمة ابن خلدون / /9 § أو مابعدها. 
_ لا يجوز تعليق إنشـاء الوقف على شـرط في IV

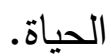

11 ـ الوقف بشرط الولاية على الوقف. 19_ الوقف بشرط التصرف.

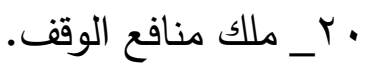
YY_ يصح تعليق الواقف الوقف على موته. r Y _ الوقف في مرض الموت بمنزلة الوصية.

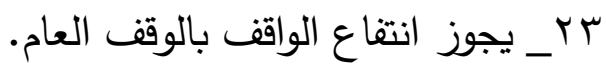
ـ _ _ لا ينتفع الواقف بالوقف الخاص. هب _ التصرف بفضل أثاث المسجد. דr _ التفاضل بين الموقوف عليهم. Y _ الوقف على البنات يختص بهن. TV

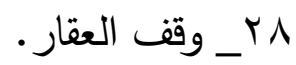
9ץ _ جواز وقف الأرض للمسجد. • بــ جواز وقف الأرض للمقبرة. ابr وقف ما تزول عينه بالانتفاع. rr_ إذا خرب الوقف لم يعد لملك الواقف. rr_ لا يصح تخصيص النفس بالوقف. ـ ـــ ضمان الوقف المتلف بالغصب.

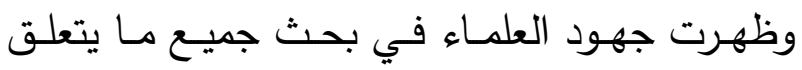
بالوقف من المسائل المختلفة في ظهورها ودقتها ولا يزال الباحثون يكتبون في هذا المجال ؛ مدا يجعل فيل فئل

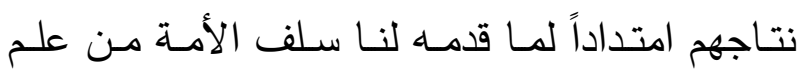
غزير في هذا المجال وفي غيره. وقد جعلت الدولة الإسـلامية جهات مختصـة ووزارات للإشراف على الأوقاف وإدارتها وتوجيه مواردها.
والمسـتجدات؛ ولا تــزال الجامعـــات تقـــم رســائل ومؤتمرات خدمة لهذا الباب. وسأذكر جزءً من جهودهم في ذكر بعض أحكام لهذام هذا الباب إجمالاً: - البال ' _ الوقف جائز من حيث الجملة . Y _ حكم تحبيس الأصل على التمليك وتسبيل الغلة.

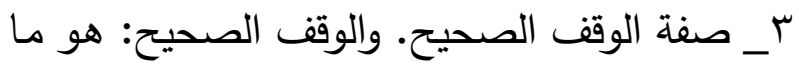
كان معلوم الابتداء والانتهاء، مثل أن يجعل نهايته

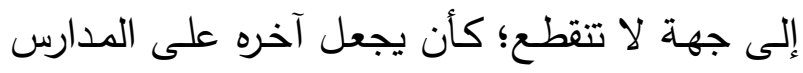
أو على المساكين. ع_كون الوقف من الطاعات . __ لا وقف على ما ليس بطاعة.

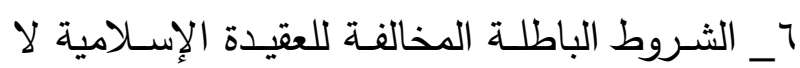
تصح في الوقف ولا في غيره.

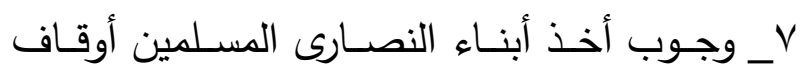
آبائهم النصارى الموقوفة على البيعة. ^__ حكم إكراء الوقف لمن يضر به. 9_ المسجد الموقوف ليس ملكاً لمعين.

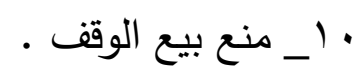
'I _ إذا تعطلت منافع الوقف فيجوز استبداله. r Y _ جواز بيع الفرس الحبيس إذا تعطلت منافعها.

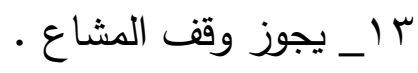
ع إ_ وقف ما لا يحتمل القسمة. 10_ ـ وجوب أن يكون الوقف دائماً. 17

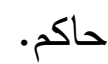


الذي توفر لهم من قبل الأوقاف أتثره البالغ في ذلك البناء.

المطلب الأول: منع بيع الوقف العلمي. وهو أهم الفروع الفقهيـة التي تجعل الوقف العلمي التولي مورداً مالياً لا ينضب. الفروع.

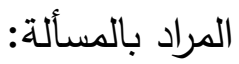
أن من وقف شينًا وزال ملكه عنه سواء بنفس الوقف بـف

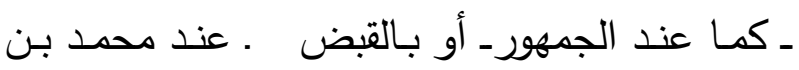
الحسن، والمالكية ـ أو بحكم حاكم ـ عند أبي حنيفة.

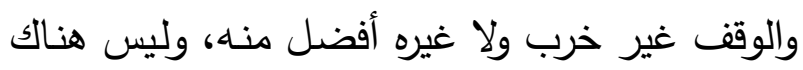
مصلحة راجحة في بيعه ؛ فإنـه لا يجوز للواقف ولا

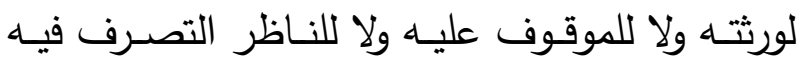
ونبيع ولا هبة ونحوهما (Г).

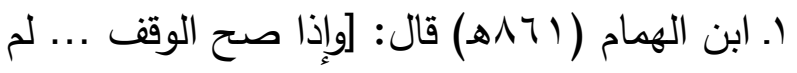
يجز بيعه ولا تمليكه ... بإجماع الفقهاء]"(r).

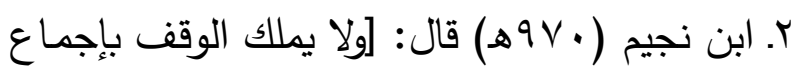
الفقهاء [) (؟) أن

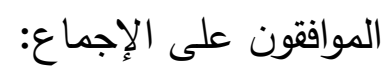

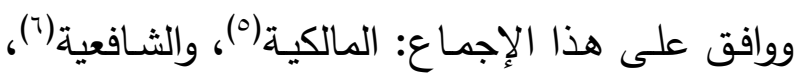

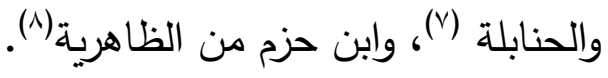
ويستتد هذا الإجماع على عدة أدلة، منها:

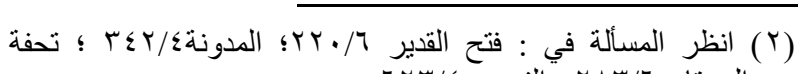

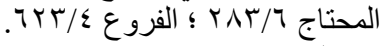

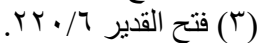

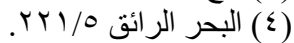

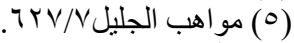

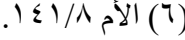

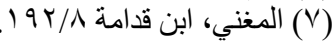

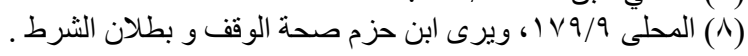

ويجب على الباحث الرجوع إلى ما قيده الفقهاء في كتبهم حتى لا يقـع في حكم شـاذ أو ترجيح لـرأي

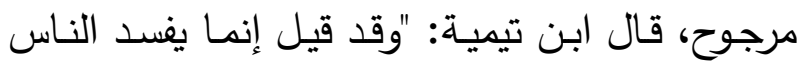
نصف متكلم ونصف فقيـه ونصف نحوي ونصف طبيب هذا يفسد الأديان وهذا يفسد البلدان وهذا يفسد ونئ وندان

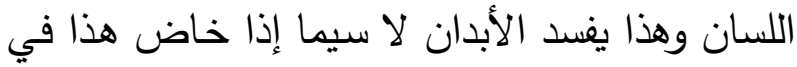

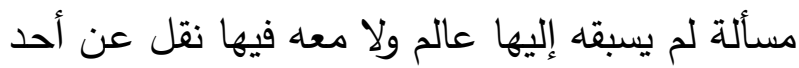

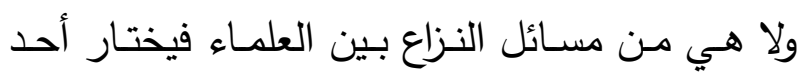
القولين؛ بل هَجْمُ فيها على ما يخالف دين الإسـلام

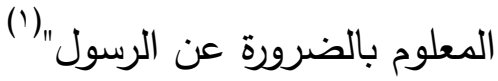
المبحث الثاني

أهمية الوقف العلمي في حياة المسلمين. وفيه مطلبان: المطلب الأول: منع بيع الوقف العلمي.

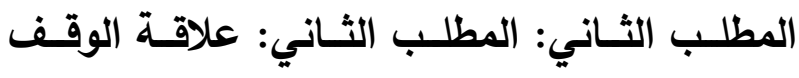
العلمي بمقاصد الثريعة. توطئة: لقد كان الوقف من أهم وسائل التقدم العلمي والفكري

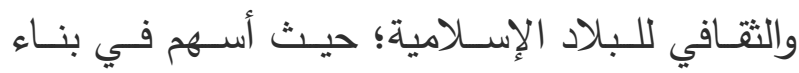
صروح العلم ونشرها عن طريق المساجد والكتاتيب

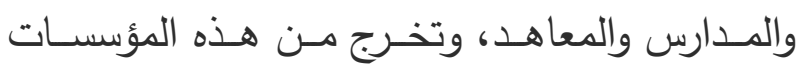

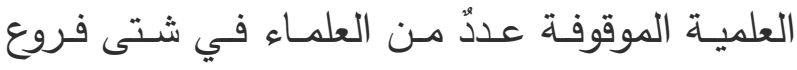
المعرفة البشرية مثل: الخوارزمي، وجابر بن حيان، وابن سينا، والرازي، وابن الهيثٌ، وكان للدعم المادي 
المختلفـة. ويزخـر العـالم الإسـلامي بعدد كبيـر مـن المدارس الوقفيـة مثثل: المدرسـة النظاميـة، والمدرسـة المستتصــرية، ومدرســة ابـن الجــوزي، والمدرســة السـليمانية بمصـر ، ودار السلسـلة، ومدرسـة الملـك

المنصور عمر، ومدرسة الملك الأفضل (). ولا يقتصــر دور الوقــف عندـ إنشـاء المــدارس؛

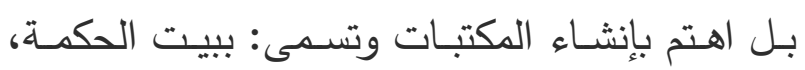
ودار العلم، وخزانة الكتب، ودار الكتب، وتم تزويدها

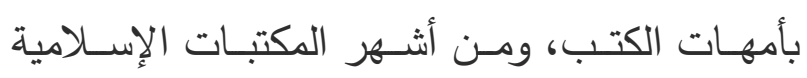
الموقوفة: مكتبة الموصل، مكتبة بغداد بالعراق، ودار

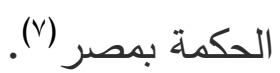

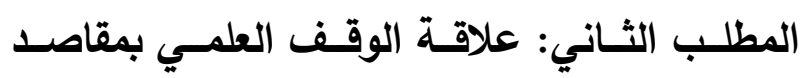
الثريعة.

تتجلـى أهميــة الوقـف العلمـي خاصــة فـي حيـاة المسلمين من خلال العلم بالحكمة، والمقصد، والغاية مــن مشـروعية الوقـف إذ أن تكــاليف الشــريعة الإســلامية ترجـع إلى حفظ مقاصــدها في العبـادة، والمقاصد ثلاثة أقسام: 1- ضرورية : فالضرورة معناها أنها لابد منها في قيام مصالح الدين والدنيا .

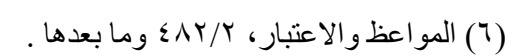
(Y)

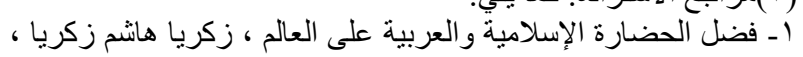

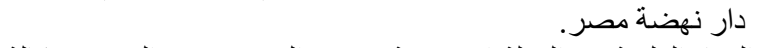
r- الحياة العلمية فى الدولة الإسلامية، محمد الحسينى عبد العزيز، وكالة

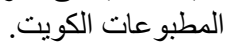

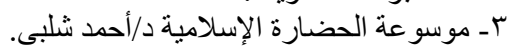

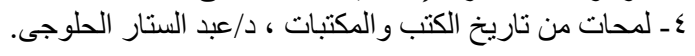

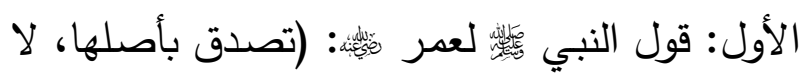

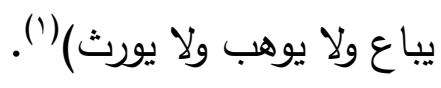
وجه الاستدلال: أن الأصل في الوقف بولف أنه لا يباع ولا

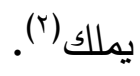
الثاني: أن الأصل هو تحريم بيع الوقف، وإنما أبيح للضرورة صيانة لمقصود الوقف من الضياع(َ).

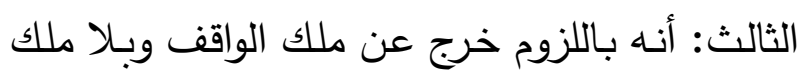
لا يتمكن من البيع ولا التمليك بوجه آخر (๕).

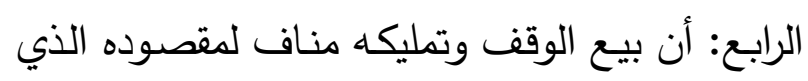
هو تحبيس الأصل وتسبيل المنفعة (o). كما أن الوقف العلمي قد اهتم برعاية طـلاب العلم

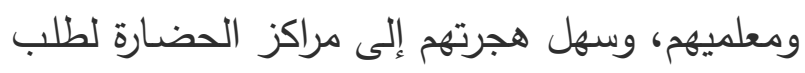

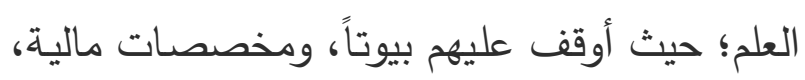

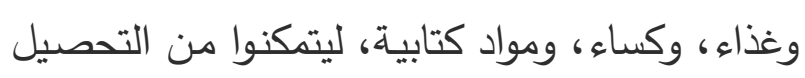

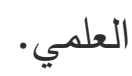
ولم يقف أثر الوقف في التعليم عند علم معيَّن بحد

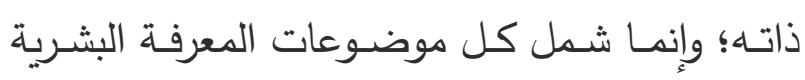

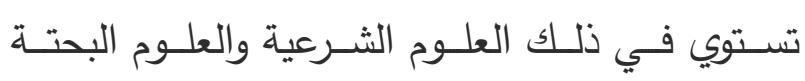

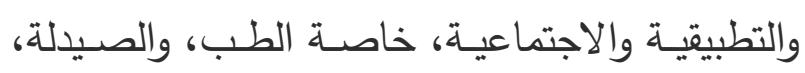
والفلك. ولقد سـاهم الوقف بشكل ملحوظ في نشـر

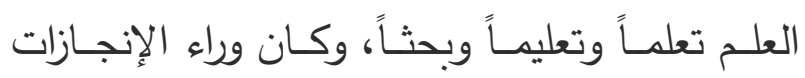

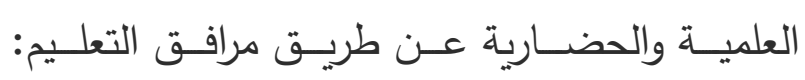

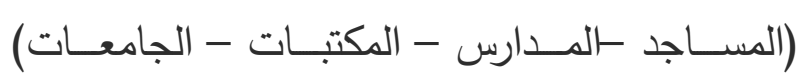
(1) أخرجه البخاري، كتاب : الوصايا، باب: الوقف كيف يكتب، رقم

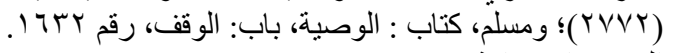

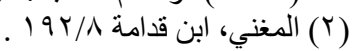

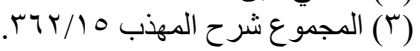

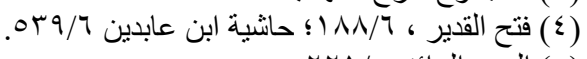

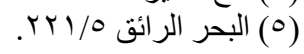


بتوفير احتياجاتهم ودعم تطورهم ورقيهم ـ كمـا أنـه ربط الخلف بالسلف كما في قوله

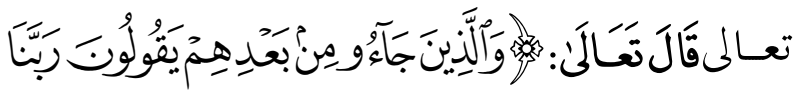

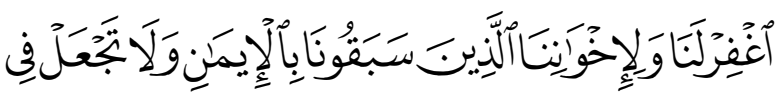

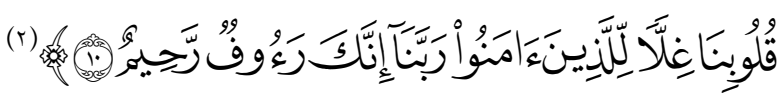
وإن الدعم المـادي المقطوع للمؤسسـات العلميـة قد

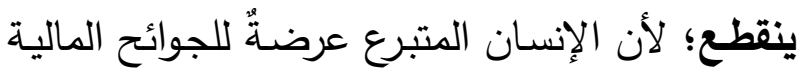

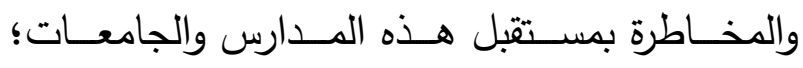
والأجدر في دعم العلم والعلماء والطلاب هو بضمان الاستمراية وبقاء السيولة - بإذن الله تعالى - لهذاء ولهاب المورد في كل وقت تحتاج إليها؛ والذي يحقق ذلك بلك الكاءل

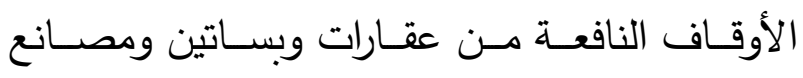
ونحوهـا، فيان سيولة مثل هذه الأمسور تكون دائمــة

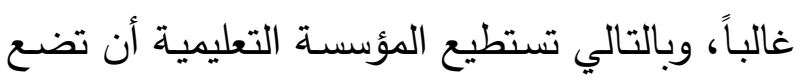
برامجها على هدى وبصيرة، وتؤدي رسالتها العلمية على الطريقة المرضية. ولا أدل على ذلك من الأزهر الذي شع نوره نحو ألف لف

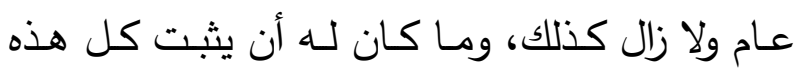
الفترة لـولا الوقف العظيم الذي أغنـاه عن التقلبـات السياسية التي تؤثر عليه وتعاقب الحكام واختلاف

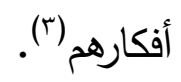

(r) سورة الحشر ، آية ل1 . . النظر: مجلة الجامعة الإسلامية،

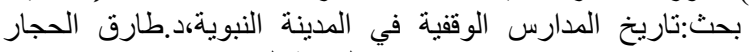

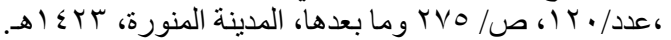

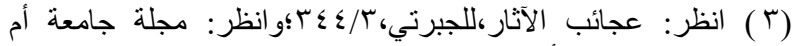

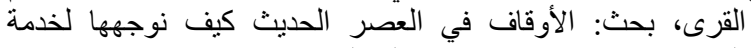

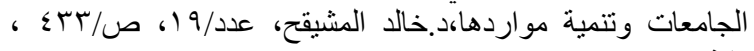

r-حاجيـة: والحاجيات معناهـا أنها يفتقر إليها من

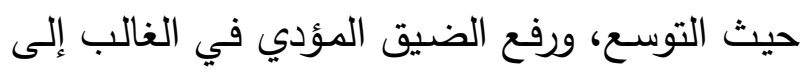
الحرج، والمشقة اللاحقة بفوت المطلوب.

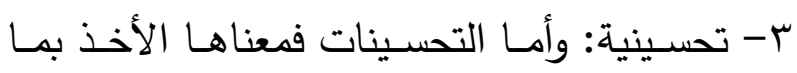
يليق من محاسن العادات، وتجنب الأحوال المدنسات التي تأنفها العقول الراجحات (')، والوقف لا شك التك أنه

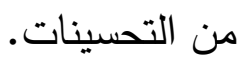
والوقف من هذا الجانب يتميز عن بقية الصدقات والهبات بأمرين: الأول: الاستمرارية: وهو: ا- استمرارية الأجر والثواب وهذا هو المقصود من من الوقف من جهة الواقف.

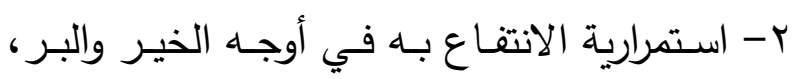

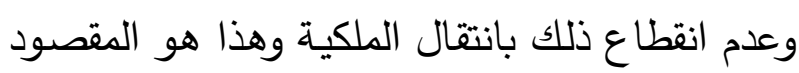
من الوقف من جهة انتفاع المسلمين به . الثاني: الاستقلالية :

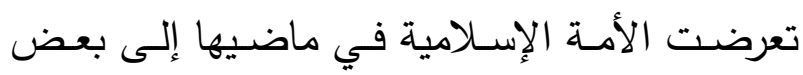
الثدائد والمحن أدت إلى وقوع بعضها تحت سيطرة

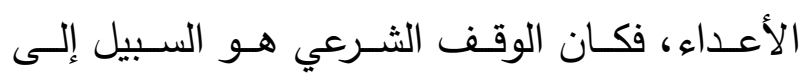

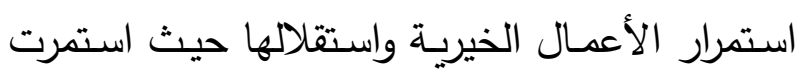
المناشـــ الدعويـة، والتعليميـة، والإغاثيـة، والإنفــاق على المدارس، والمساجد، والأربطة، والمكتبات . كما أن للوقف فوائد من الواقع الملموس والمشاهد والاربه، وأنه

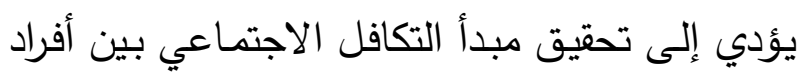

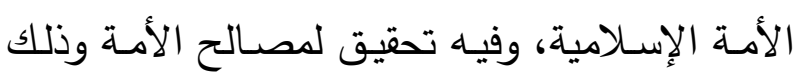

$$
\text { (1) (انظر : علم مقاصد الثار ع، للربيعة، ص/ ؟ ؟ ا وما بعدها. }
$$


صح بيعه صح وقفه. وجاء في مجموع الفتاوى [..

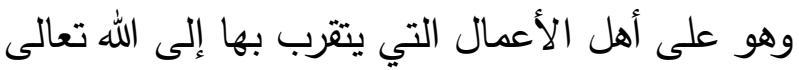

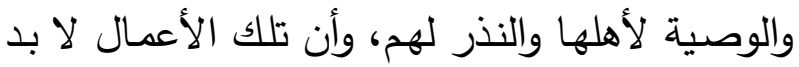
أن تكون من الطاعات التي يحبها الله ورسوله، فإذا لإنا كانت منهيًا عنها لم يجز الوقف عليها، ولا اشتراطها في الوقف باتفاق المسلمين](؟).

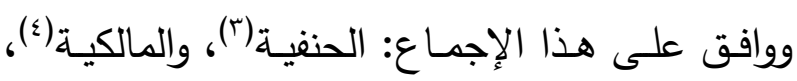
والثافعية (0.) ويستتد هذا الإجماع على عدة أدلة، منها:

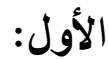
قَالَ نَعَالَنَّ:

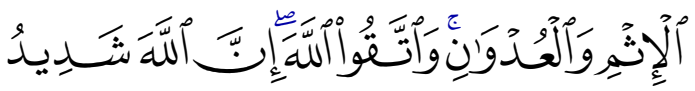
آلِْقَّابِ (1) وجـهـ الالسـتـلال: فيـه حرمسة التعـاون علـى الإثم

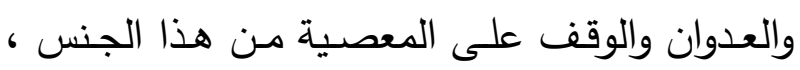
والله الثاني: أن المقصود من الوقف القربة، والواقف يرجو

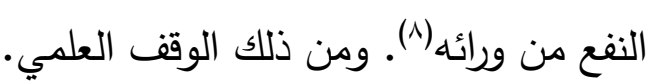

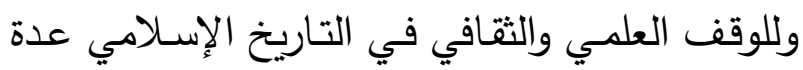

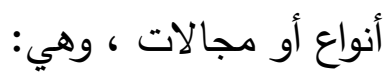

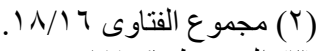

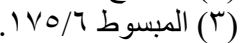

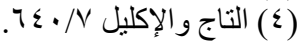

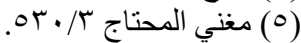

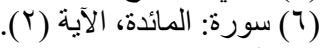

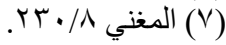
(^)
المبحث الثالث: مجالات الوقف العلمي وتطبيقاته في التاريخ الإسلامي. وفيه مطلبان:

المطلب الأول: مجالات الوقف العلمي في التاريخ الإسنلامي. المطلب الثاني: الأمثلـة التطبيقيـة التاريخيـة على الأملى الأوقاف العلمية . المطلب الأول: مجالات الوقف العلمي في التاريخ الإسنلامي: (') ومـن الفـروع الفقهيـة الهامــة فـي مجـالات الوقـف

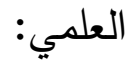
مسألة:وجوب كون الوقف من الطاعات. توطئة: - ت ن لهذه المسألة علاقة قوية في مجالات الوقف العلمي؛

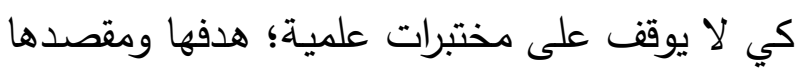

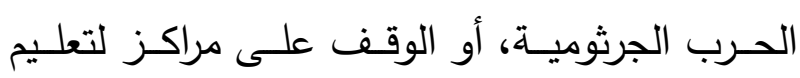

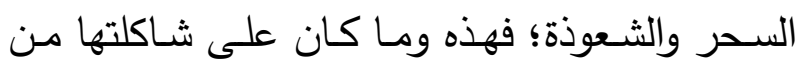

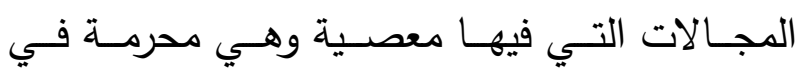

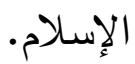

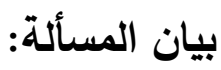

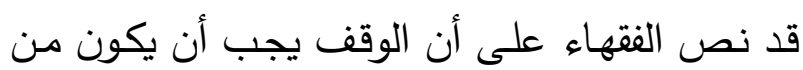

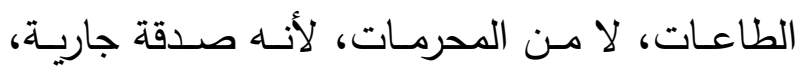

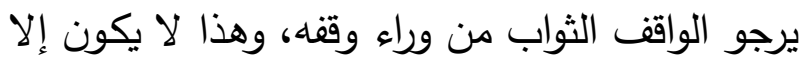
في ما هو من قبيل الطاعات فلا يجوز وقف الخمر ،

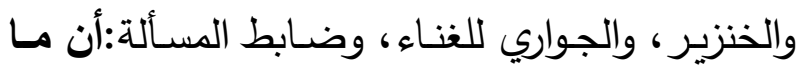
(1) اللفائدة: انظر :بحث الوقق الثقافي والعلمي، أهميته و أنواعه، د/أحمد 
لقرون عديدة، إن حوفظ عليه وكان بأيدي أمينة؛ كما أثبت ذلك التاريخ في كثير من البلدان.

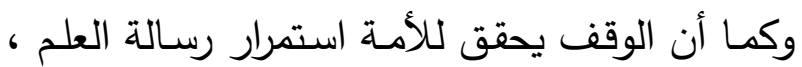
وبقـاء هـذه الرسـالة يعنـي دوام حياتهـا، فإنـه يحقـق كذلك ما هو أهم في نظر كثير من الناس ألا وهو - الأجر العظيم

وسبق بيان مشروعية الوقف والحث عليـ؛ ولا شك أن الذي يوقف ماله ويحبسه على مدرسة أو جامعة إنما علَّم أمماً وربى أجيالاً تقود أُمَماً. ولا شـك أن المـدارس هـي أول المؤسسـات التعليميـة التي تسـهم الإسـهام الفعـال في نشـر الثقافـة والعلم، لذلك كانت أولى المؤسسات جدارة بالأوقاف الفاعلة لتسهيل حركة التربية والتعليم . لقد أشـاد العلامـة ابن خلدون في مقدمته وهو ينوِه ببقـاء العلم بالمشـرق، ويرجـ السـبب في ذلك لكثرة عمرانــهـ والحضـــارة ووجــود الإعانــة لطالــب العلــم بالجراية من الأوقاف التي اتسعت بها أرزاقهم(ْ). ثانياً : الوقف على المساجد:
أولاً: الوقف على المدارس: لقد عنى الإسلام بالعلم عناية فاقت عناية غيره على الإطلاق من غير منازع في العلم والثقافة منذ بداية الـوحي على رسـول الله - صــلى الله علبـهـ وسـلمحيـثُ حـثَّ على طلب العلم والمعرفـة، ومـن خـلال أول آية نزلت على خاتم الأنبياء والمرسلين؛

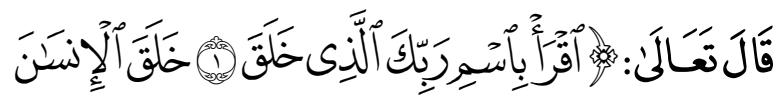

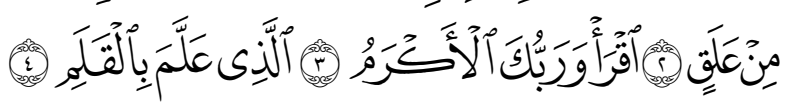

(1) فتـرى كيـف اسـتهل الله تعـالى كتابـه الكـريم بطلـب القراءة، ثم كرر الطلب للتأكيد على أهميتهـ ثم نوَّه بالعلم ، وأداة العلم: القلم ، وامتن على الإنسان بـه ، وقد اقترن ذلك كله بنعمة الخلق، إيذاناً بأن العلم هو روح الوجـود ، وأنــهـه بغيـره مفتـود (r)، قـال الإمــام البخاري: باب العلم قبل القول والعمل()؛ فقدم العلم

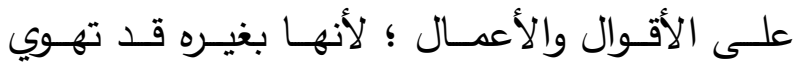
بصـاحبها في أسـفل الـدركات، فـالعلم شـرط لقبـول

العبادات وصحة المعاملات (ع). وحيث إن الثراء وحده لا يكفي لتحقيق هذا الغرض لقلتهـ في النـاس وتقلبـه بيـنهم فكـان لابـد مـن ريــع مستمر لضمان بقاء رسالة العلم منيرة في الأرض. وأفضل مـا يحقق ذلك هو الوقف على المؤسسـات العلميـة أو العلمـاء، فإنـهـ يسـتمر مثــراً ثــرة يانعــة

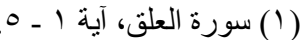

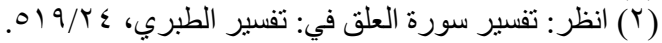

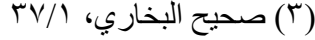

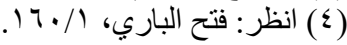




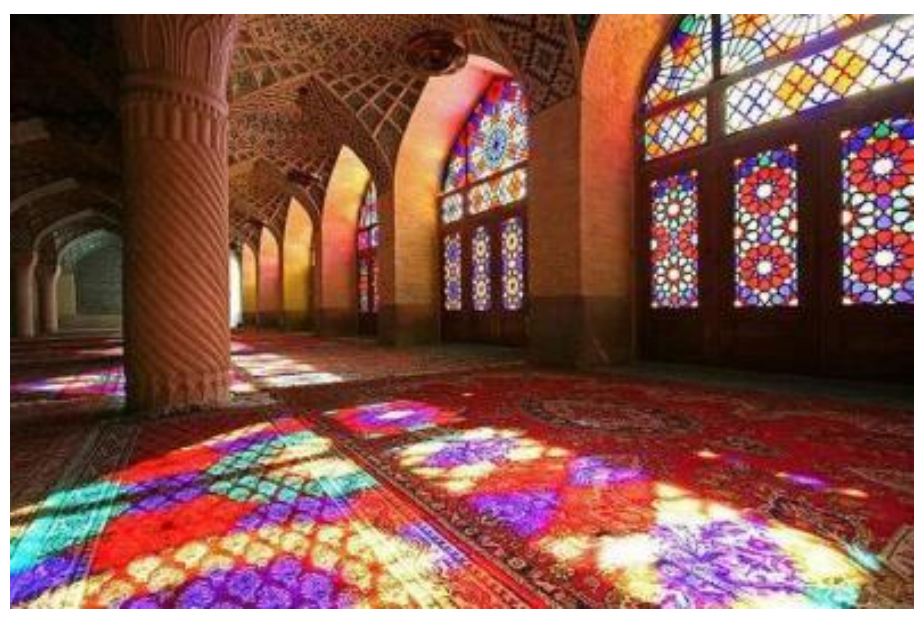

وقال صلى الله عليها وسلم (من بنى مسجداً يبتغي

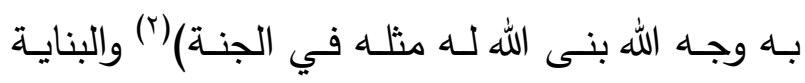
التي ذكرت في الحديث وإن تناولت في المقام الأول البنايـة الحسية وهي تشييد البنيان، غير أن بناءهـا معنويـاً بإحيـاء ذكـر الله تعـالى فيهـا وتيسـير أداء رسالتها هو أيضاً من بنائها وعمارتها؛ كما دل على لى دئ ذلـك:قولـهَتَالَّن:

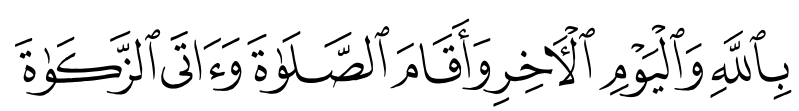

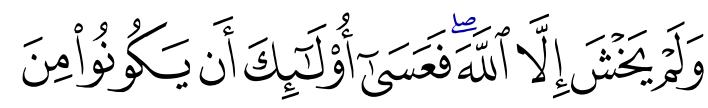

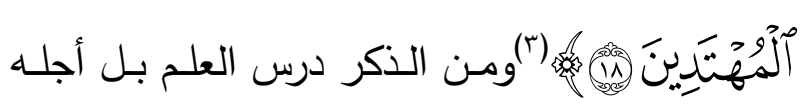

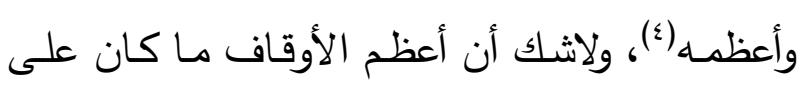

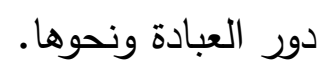

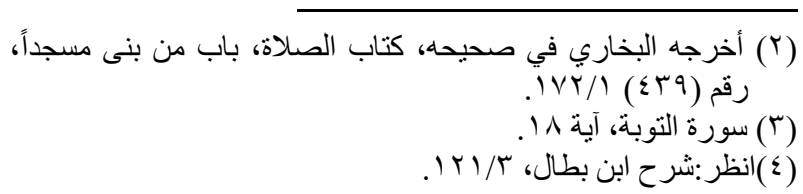

كانت المساجد في الإسـلام تؤدي مهامـاً زائدة على الصـلوات الخمس وخطـب الجمعـة؛ فهـي مـدارس لهـ علمية في مختلف الفنون، وملتقى العلماء والأدباء . وكما كانت عناية الفقهاء والولاة بالمدارس لأهميتها الثقافية فبنوا أطلالها وحبسوا لها الأحباس التي تحقق لها القيام بأداء دورها على أحسن حال؛ فكذلك كانت عنايتهم بالمساجد لأهميتها الروحية والثقافية على حد سواء؛ ذلك أن النصوص الثرعية التي وردت في الحث على الوقف تحفز المسلم على أن يبادر إلى أحب القرب إلى الله تعالى، ولا شك أن أحب القرب لديه سبحانه ما تعلق بأحب البقاع عليه؛ وقد أضافها لنفسها قَالَ تَعَالَنا: (1) (11 
ونحوهم مسن المهمـات التي لابد من تحقيقها لتلك المؤسسات الحضارية.

ولا يمكن أن تقرأ لمدرسة في قروننا الأولى أو تسمع عنها إلا وتعرف ما يلحق بها من رُبُط بنيت لفقراء الطلبة والذين يفدون إلى البلاد؛ بل وفقراء البلد كذلك

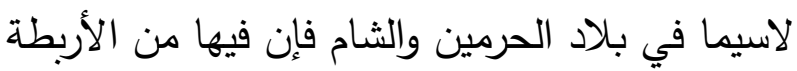

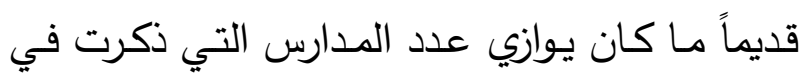

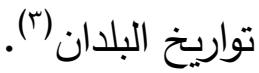
رابعاً: وقف الكتب والمكتبات:

إنَّ المدارس والمساجد لا وتستغني عن الكتب العلمية التي يصعب توفرها إلا بالاعم المتواصل وتخصيص وله أماكن محددة لحفظها والعناية بها وتعيين من يقوم بإدارتها ؛ لذلك فإنمهمـة الوقف لا تقفت عند إنشـاء المدارس؛ بل اهتم الواقفون بإنشاء المكتبات وتزويدها بأمهـات الكتب، ومـن أثـهر المكتبـات الإسـلامية الموقوفة: مكتبة الموصل، مكتبة بغداد بالعراق، ودار

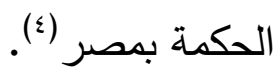
وانتشـرت خـزائن الكتـب الوقفيـة منــــ القـرن الرابـعـع الهجري ، بحيث يمكن القول بأنـه قلمـا تخلو مدينـة من كتب موقوفة . وبلغ من انتشار هذه الخزائن وتوافرها في الأندلس أن موهاه أبا حيان التوحيدي النحوي كان يعيب على مشتري

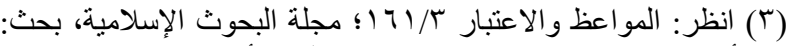

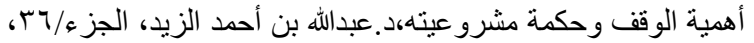

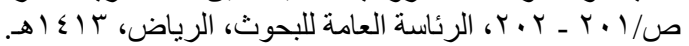

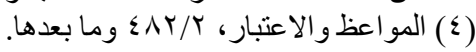

ثالثاً: وقف الأربطة وما يصلحها: كمـا كان للوقف على المدارس والمسـاجد مهماً لمـا

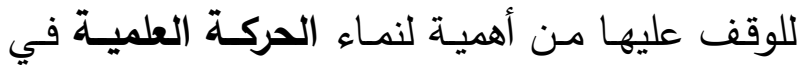
الأمسة الإنسـلامية فإن وقف مسـاكن للطـلاب ورواد

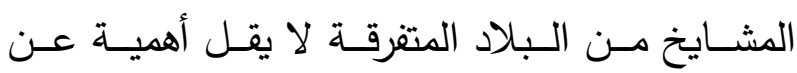
المدرسة والمسجد. والأربطـة: كانت في بدايتها تستعمل للجند؛ لحراسـة الثغور في معظم الدول الإسـلامية وبـرور الزمن

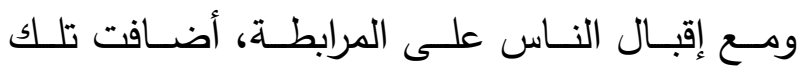

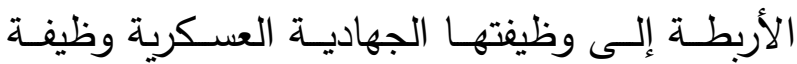
التدريس والتأليف من قبل العلماء والفقهاء المرابطين فيها، وقد حظيت باهتمـام المسلمين فكثر الواققون عليها. وخلال القرن الثالث والرابع الهجريين ازدهرت

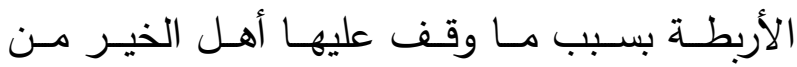
الإمداد. فقصدها طلاب العلم من كل صوب لطلب العلم ومما ساعد على ذلك وجود السكن والإعاشة. ثم أخذ بعض العلماء والمشايخ والفقهاء يقيمون بها؛ وماء فوفد إليها من يتلقى عنهم العلم والفنون المختلفة بها.

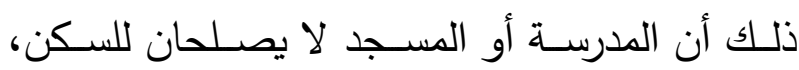
وإصـلاح الحال، ولابد للطالب من ذلك حتى تستقيم حاله ويستطيع أداء رسـالته في الطلب والتحصيل، ومـن القواعـد المسـلمة أن " الوســائل لهــا أحكــام

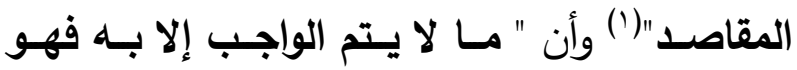

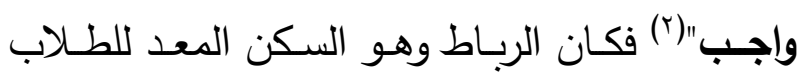

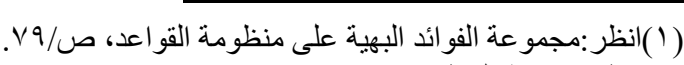

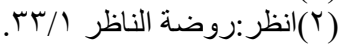


الكتب، ويقول: اللَه يرزقك عقـلا تعيش بـه، أنـا أيُّ توطئة:

إن الأمثلة التطبيقية عبارة عن لمحة مختصرة على

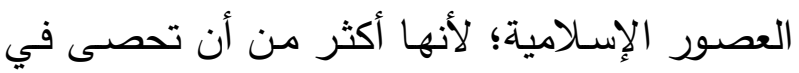

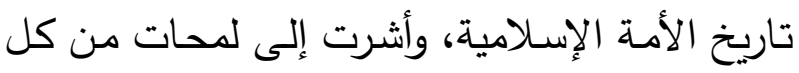

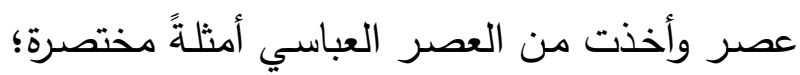
لأن العصر العباسي زاخرٌ بالأوقاف العلمية ويحتاج إلى دراسة تطبيقية خاصة. العهد الأول: العصر النبوي: يُرْوَى أن أول وقف في الإسـام كان صدقة الرسول

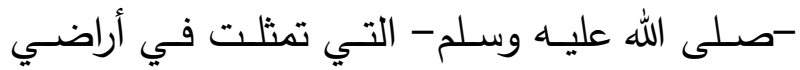
مخيريق كرضـي الله عنـه، الذي أوصسى قبل معركـة

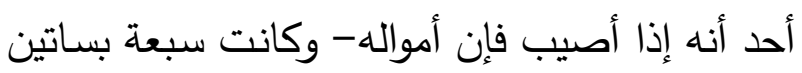
بالمدينـة لمحمد - صلى الله عليـه وسـلم- يضـعها حيث أراه الله وقتل مخيريق في غزوة أحد، فأصبحت أمواله في عامـة صدقات الرسول - صلى الله عليه

وسلم- فأوقفها عليه السلام (๕). العهد الثـاني: عهد الصـحابة رضـوان الله عليهم

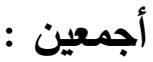
كـان الصـحابة-رضـي الله عنهم- هـ أكثر ترسماً لخطوات الرسول - صلى الله عليه وسلم - ومتابعةً لهديه؛ قال جابر : "لم يكن أحد من أصحاب النبي لهي وسله

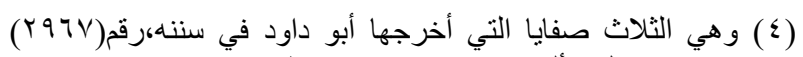

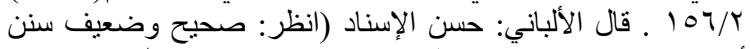

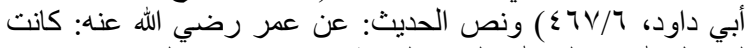

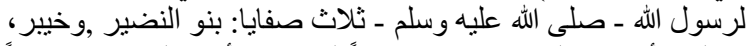

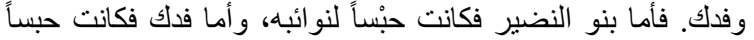

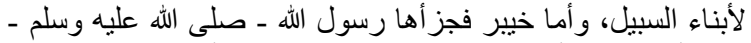
ثلاثة أجز اء: جزأين بين المسلمين، وجزء ألهاء نفقة لأهله، فما فضل عن لهن نفقة أهله جعله بين فقر اء المهاجرين)

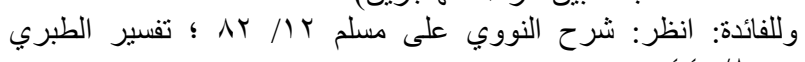

كتاب أردته استعرته من خزائن الأوقاف (').

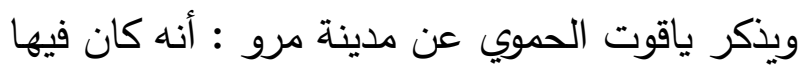
عشر خزائن للوقف وذلك في القرن السـابع الهجري

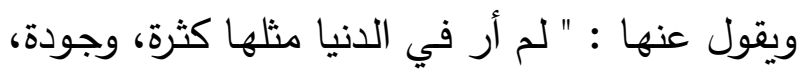

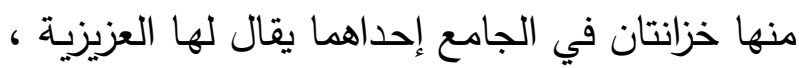

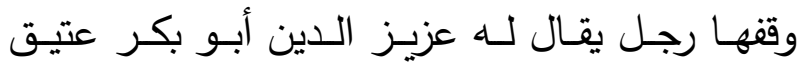

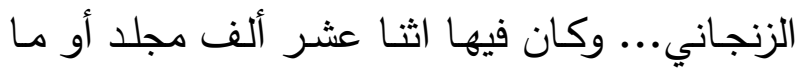

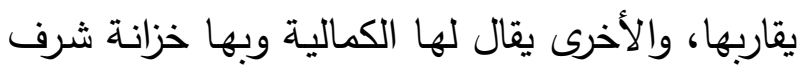

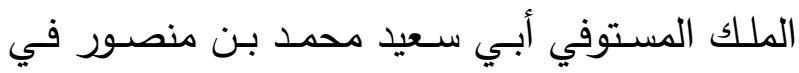
مدرسته ، وخزانة أخرى في المدرسة العميدية وخزانة

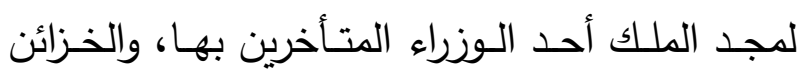
الخاتونية في مدرستها والضميرية في خانكاه هنالك

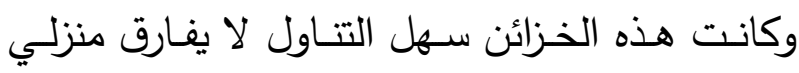
منها مئتا مجلد ، وأكثره من غير رهن"((†) .

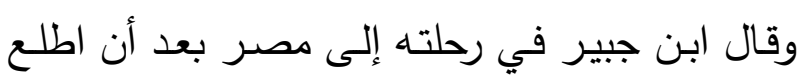

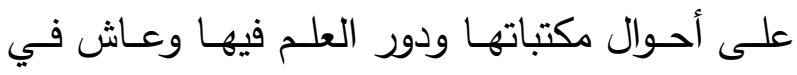
بعضها، واستفاد من أموالها الموقوفة : ومن مناقب

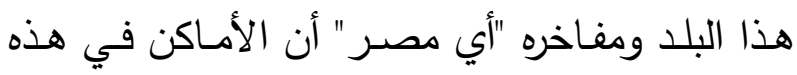

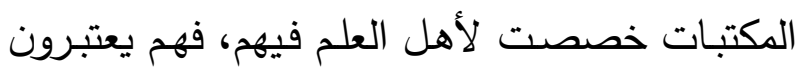
من أقطار نائية فيلقى كل واحد منهر مأوى إليه ومآلاً

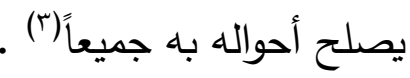

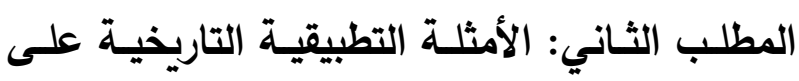

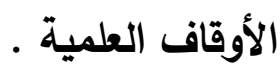

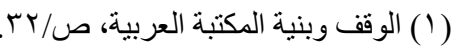

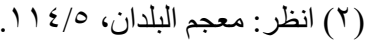

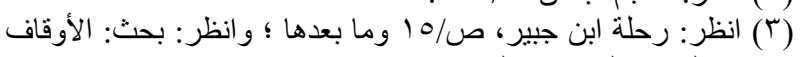

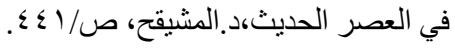


وأوقف علي بن أبي طالب -رضي الله عنه- بستاناً على الفقراء والمساكين وفي سبيل الله وابن السبيل والقريب والبعيد في السلم والحرب(؟). كما أوقف الزبير بن العوام -رضي في الله عنــ- دوره

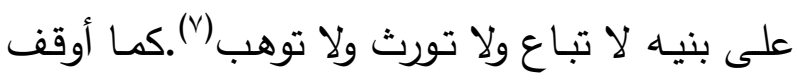

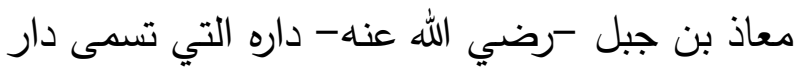

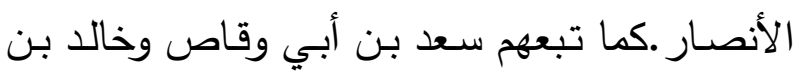

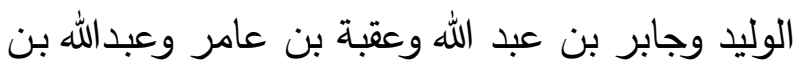

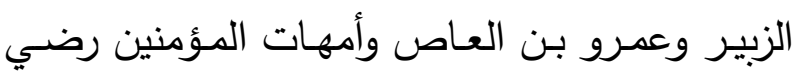
الله عنهم (^). وقد توالت أوقاف الصحابة -رضي الله عنهم، وسار على نهجهم المسلمون في كل زمان ومكان يوقفون أموالهم وينفقونها تقرباً لله تعالى راجين رحمته وغفر لهرانه

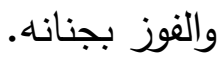

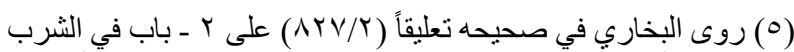

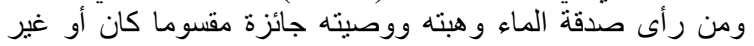

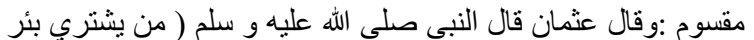

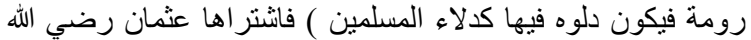

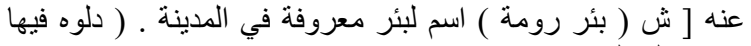

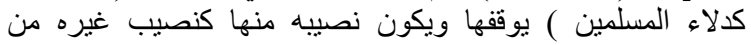

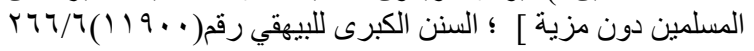
و

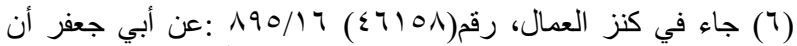

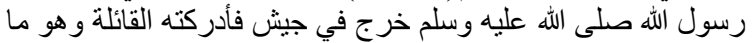

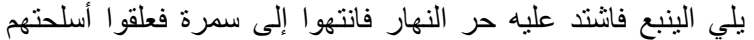

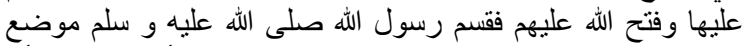

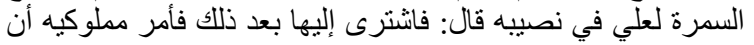

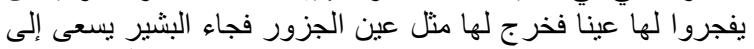

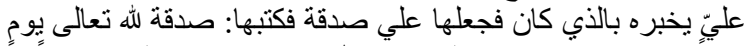

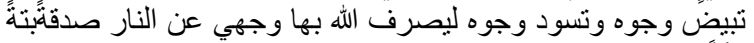

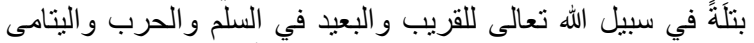

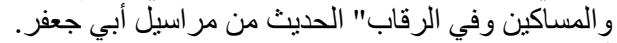

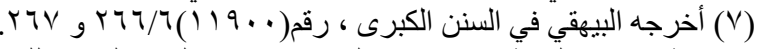

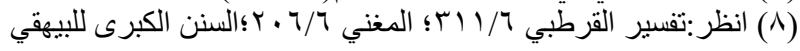

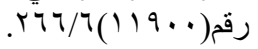

صـلى الله عليـه وسـلم ذو مقدرة إلا وقفـ"( )، وقـال الثـافعي - رضـي الله تعـالى عنــه - فـي القـديم: "بلغني أن ثــانين صـحابيا مـن الأنصـار تصـدقوا بصــدقات محرمــات" والثــافعي يســـي الأوقـاف الصدقات المحرمات.(؟) فقد حبَّس أبو بكر الصديق - رضي الله عنه- رباعاً له بمكة المكرمة(r) - له وأوقف عمر بن الخطاب -رضي الله عنـ- الأرض التي أصابها بخيبر كما تقدم (ء). وأوقف عثمان بن عفان -رضي الله عنه- بئرَ رومة التي اشتراها وأوقفها للسقيا(ْ). (1) أخرجه أبو بكر الخصاف في: أحكام الأوقاف(10) ؛ ؛ ؛ وذكره الألباني

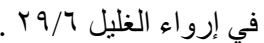

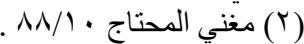

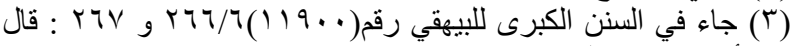

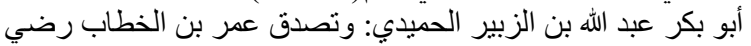

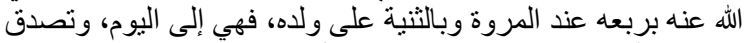

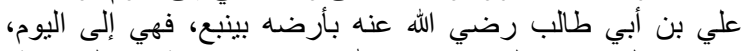

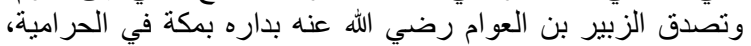

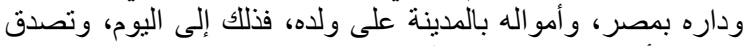

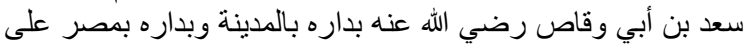

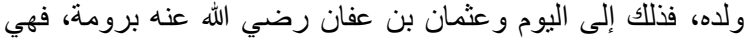

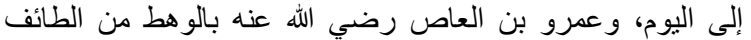

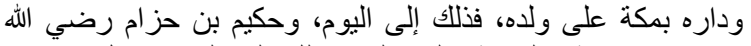

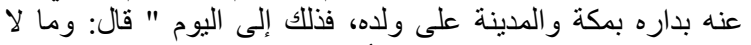

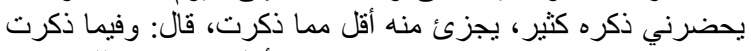

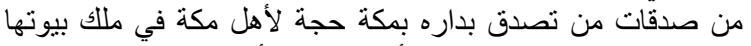

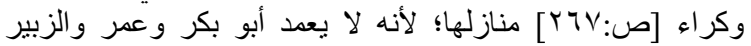

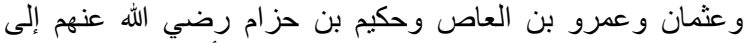
شيء الناس فيه شرع سواء فيتصدقون به على أو لادهم دون مالكيه معهم.

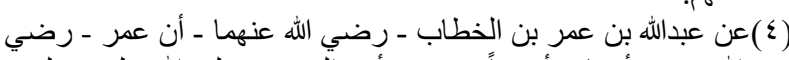

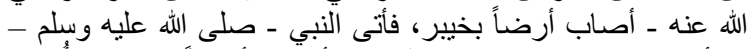

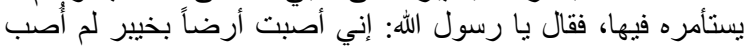

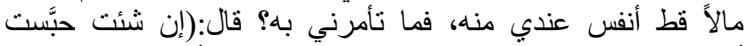

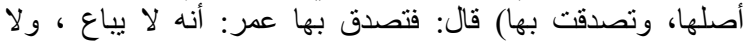

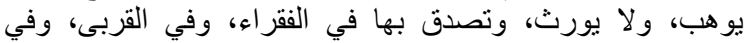

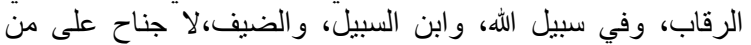

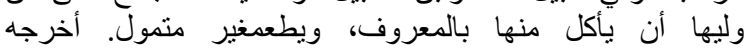

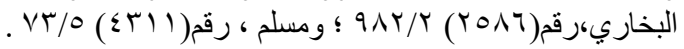


كثرت الأحبـاس كثرة ملحوظة واتسـع نطاقها ، ممـا كان سـباً في أن يجعـل للأوقاف ثلاثـة دواويـن : ديوان لأحباس المسـاجد ، وديوان لأحباس الحرمين الثـريفين وجهـات البـر الأخـرى المختلفـة ، وديـوان للأوقاف الأهليـة، وكمـا أنشأ الفاطميون ديوانـاً عامـاً للأوقاف بمصر (r)، وعزز ذلك الأيوبيون. ثم انتشرت الكتاتيب العامـة الموقوفة بعد ذلك عبر العصور حتى أصبح الكتَّاب في بلاد ما وراء النهر يضم الأطفال اليتامى والفقراء والمساكين حتى أصبح كتَّاب الضـحاك بـن مـزاحم يحتوي على أكثر مـن ثلاثـة آلاف طفـل. كمـا أصـبحت بالشــام كتاتيـب موقوفـة لتعليم أبنـاء المسـمين حول الجـامع الأمـوي بدمشق • ثم تلا بعد ذلك الكتاتيب في مصر وفي عهد المماليك ثم الدولة العثمانية وخصوصاً الكتاتيب التي أقامتها في مكة المكرمة والمدينة المنورة، حتى

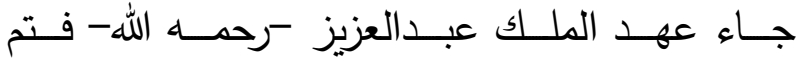
الاستغناء عنها بالمدارس النظامية المجانية(£). العهد الخامس: عهد العثمانيين : في عهد العثــانيين: فقـد "كثر عـدد الزوايـا في القيروان خلال العصر العثماني، ولقي بناؤها تشجيعًا من الحكام، بـل إن بعضـهم سـاهم في إنشـاء العديد منها، ووقفوا عليها العقارات الكثيرة، وأعفوا بعضـها من أداء العشر ، وخصصوا لها جرايات دورية"(0). (T)(انظر: مجمو عة محاضرات في الوقف،صاص/ع (؛ و وانظر: بحث: أهمية

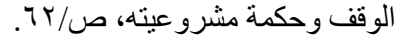

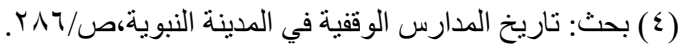

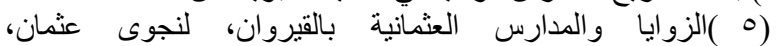

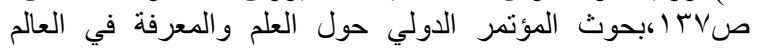

العهد الثالث: عهد الأموبن:

ولمــا كـان زمـن هثـام بـن عبـد الملـك ، صــارت للأوقاف إدارة خاصة بمصر تشرف عليها وترعاها ، وأول من فعل ذلك توبـة بن نمر قاضـي مصر ، فقد كانت الأحباس في أيدي أهلها وفي أيدي الأوصياء فلما تولى توبة قال :"ما أرى مرجع هذه الصدقات إلا إلى الفقراء والمسـاكين ، فأرى أن أضـع يدي عليها حفظاً لها من الضياع والتوارث" . ولم يمت توبة حتى صار للأوقاف ديوان مستقل عن بقية الدواوين يشرف عليه القاضي. وكانــت الأوقـاف التـي خصصــت منفعتهــا للفتـراء والمساكين آنذالك بأيدي واقفيها فتسلمها منهم القاضي توبة بن نمر وتولى الإشراف عليها. ثم تطورت إدارة الأوقـاف حتى شـملت الأراضـي الزراعيـة والجوانـب

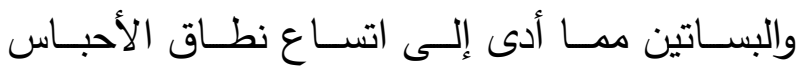
وجهات التصدق ('). العهد الرابع:العهد العباسي)(r): انتشرت الأوقاف العلمية في العراق حتى دمِّر كثير منها سنة سقوطها 707هـ على أيدي التتار وأهمها المكتبـات العلميـة، وكـان يتولى ديـوان الأوقاف من يطلـق عليه"صـدر الوقف"وقــ كانــت الأوقـاف في مصـر خاصــة تقتصـر على الدور والربـاع ، ولكن الأمـر لـم يسـتمر بـل اتجــهـ إلـى وقـف الأراضـي والبساتين واتسـع هذا الأمر في عهد المماليك ، وقد

(1) انظر: بحث: أهمية الوقف وحكمة مشروعيته،ص/ال7 ؛ مجموعة

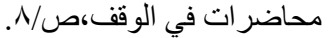

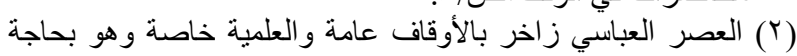
إلى در اسة تطبيقية خاصة في مجاله. 
كثيرة كلها ترمي إلى الإصـلاح من وضـع الأوقاف في البلاد حتى تتم الفائدة المنشودة(؟). وقد حافظت الدولـة على الوقف والحِكِر ، وأنشـأت أوقافاً لمساندة ودعم عدة جهات وكان أهمها: مجمع الملك فهد لطباعة المصحف الشريف، ومكتبة الحرم المكي والمـدني، ومكتبـة الملك فهد، ومركز الملك فيصـل للأبحــاث، ومكتبــات الجامعــات، وأقربهــا وأثـهرها وقف الملك عبدالعزيز في مكـة المكرمـة، وكذلك وقف المكتبات الخيرية ودعمها.

\section{الخاتمة}

أهم النتائجج والتوصيات:

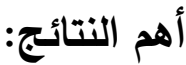
'ــ إن اخـتلاف الفقهـاء في تعريـف الوقف كـان بسـبب تعـدد الآراء في بعض أحكامـه والتقريعـات الجزئية.

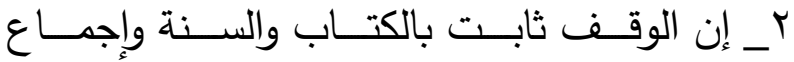

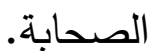
بــــذل الفقهـاء جهـوداً عظيمـة في خدمـة أحكـام الوقف؛ ممـا جعلهم يؤصلون لله ويقعدون بناء على منهجهم في ذلك؛ مما خدم المعاصرين في التخريج عليه بما يعرض من النوازل والمستجدات. ع_ عدمُ وقوف أثر الوقف في التعليم عند علم معيَّن بحد ذاته؛ وإنما شمل كل موضوعات المعرفة البشرية تسـتوي فـي ذلــك العلـوم الثـرعية والعلـوم البحتــة
وكان للحرمين الشريفين منها نصيب كبير ، وكان لها وظائفهـا التعليميـة والدينيـة، والأوقـاف الجليلـة التي تســد احتياجاتهـا، وتغنـي القـائمين عليهــا ليتفرغـوا للوظائف التعليمية والدينية المنوطة بهم. وحين تولى العثمانيون الحكم في البلاد الإسـلامية، اتسع نطاق الوقف فيها وذلك بسبب إقبال السلاطين، وولاة الأمسور وأسـرهم والمحسـنين على الوقف ومـن أجـلـ تتظــيم الأوقــاف وضــبط مصـــارفها، أقــام العثمانيون إدارات خاصـة بها، استمر العمل بها في

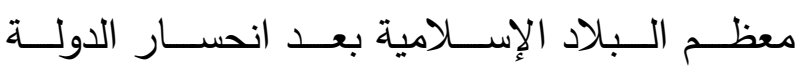

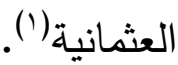
العهد السادس: الاولة السعودية: وقد جعلتُه عهداً مستقلاً؛ لوجود الحرمين الشريغين والإرث لكثيـر مـن الأوقـاف الإسـلامية فـي عنايـة

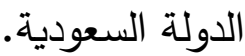
وعنـدما أتـم الله نعمـهـ على أهـل الجزيـرة العربيـة بإرسـاء الحكم للملك عبدالعزيز بـن عبدالرحمن آل سعود - رحمه الله - وبعد قيامه بتوحيد الدولة وإقامة حدود الله وشـرعه على العباد، فـإنَّ أوّل مـا اهتم بـهـ هو القضاء، والاهتمام بالحرمين الثريفين، والأوقاف

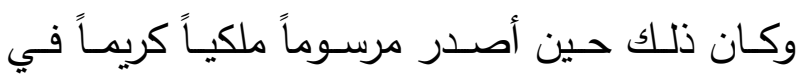

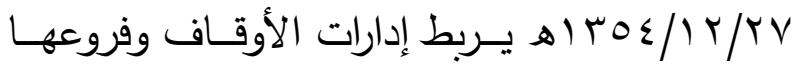
بمدير عام مقره مكة المكرمة، وتلى ذلك تتظيمات

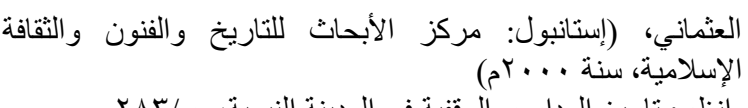

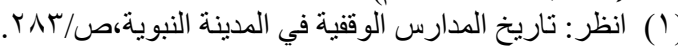


بر ـ أقام العثـانيون إدارات خاصـة بالأوقاف، وقد استمر العمـل بهـا في معظم البلاد الإسـلامية بعد انحسار الدولة العثمانية.

ع إ_ بعد قيـام الملك عبدالعزيز كحمـه الله-بتوحيد السـعودية وإقامـة حدود الله وشـرعه على العباد، فإنَّ أوّل مـا اهـتم بـه هـو القضــاء، والحـرمين الثـريفين، والأوقاف.

\section{التوصيات}

وهي هاجس كلِ باحث في هذا المجال وتطلّع الأمة لاستعادة مجدها الثقافي. لذا فـانَّ الطريـق لتشـجيع ثقافـة الوقف العلمسي بين المجتمعات الإسلامية يكون في الاهتمام بالتوصيات

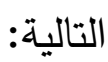
'_ـيـان المنـافع المترتبـة على الوقف العلمي، مـن خلال وسـائل الإعـلام المقروءة والمرئية والمسموعة، والدروس والمحاضرات الدينيـة، أو بأية وسيلة أخرى كالتـكير بالآيـات القرآنيـة والأحاديـث النبويـة التي تحـث على عمل الخيـر والإنفـاق على طلبـة العلم والمؤسسات التعليمية.

Y_ استصدار فتاوى شرعية من كبار العلماء بجواز الوقـف علـى المؤسسـات التعليميــة مـن جامعـات وغيرها، وعلى طلبـة العلم،ومراكز البحوث العلميـة، وإثراء حركة الترجمة؛ لأن غالبية المسلمين يعتمدون على الفتاوى الشـرعية في تصـرفاتهج، وخاصـة فيمـا يتعلق بالإنفاق في سبيل الله والوقف.
والتطبيقيـة والاجتماعيـة، خاصـة الطـب، والصـيدلة، والفلك. ـ_ كـان الوقـفُ العلمـي في تـاريخ الأمسة يحظى باهتمـام بـالغ وعنايـة السـلاطين، أمـا فـي العصـر الحاضر فهو لا يحظى بالعناية الخاصـة؛كما يحظى الوقف على الفقراء والمساكين والمساجد والمستشفيات ودور الرعاية وجهات البر الأخرى. جـ الوقف من التحسينيات التي راعاهـا الشـارع في

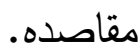
V_ يتميز الوقف عن بقية الصدقات والهبات بأمرين :الاستمرارية، والاستقلالية. ^_ كانوا يلحقون المدارس العلمية بأوقاف أخرى من رُبط بنيت لفقراء الطلبة والذين يفدون إلى البلاد؛ بـل وفقراء البلد نغسه. جـ أول وقـف في الإسـلام هـو وقف كرسـول الله صلى الله عليه وسـلم- لأراضي مخيريق كرضـي الله عنه. • ــــم يكن أحدٌ مـن أصـحاب النبـي -صـلى الله عليه وسلم- ذو مقدرة إلا وقف. أقام هشام بن عبد الملك إدارة خاصسة للأوقاف تشرف عليها وترعاها في مصر ، وكان أول من فعل ذلك توبة بن نمر قاضي مصر · r ـ في عهد المماليك كان للأوقاف ثلاثة دواوين : ديوان لأحباس المساجد ، وديوان لأحبـاس الحرمين الثـريفين وجهـات البـر الأخـرى المختلفـة ، وديـوان لأوقاف الأهلية. 


\section{فهرس المصادر}

إرواء الغليـل في تخـريج أحاديـث منـار السـبيل،

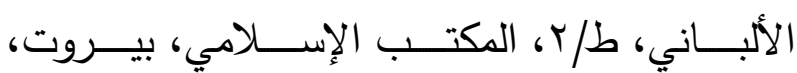

0

•الإســلام والمنــاهج الاشــراكية، محمـــ الغزالـي،

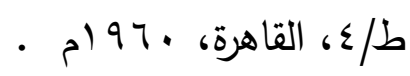

• أقرب المسالك، للدردير ، طبعة أولى.

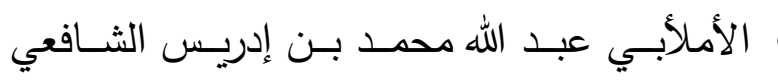

المتـوفى سـنة: ع ·ب هـ. بتحقيـق محمـود مطرجي

طبعـة الـدار الكتـب العلميـة الطبعـة الأولـى ســـة:

سا

• أهمية الوقف وحكمة مشروعيته،د.عبدالله بن أحمد

الزيد، مجلة البحوث الإسـلامية، الجزء/جس، الرئاسـة

العامة للبحوث، الرياض، ب إع اهـ.

• الأوقاف في العصر الحديث كيف نوجهها لخدمـة

الجامعــات وتتميــة مواردها،د .خالدالمشـيقح، مجلــة

$$
\text { جامعة أم القرى، عدد/9 (، مكة. }
$$

• البحر الرائقشرح كنز الدقائق، لزين الدين بن نجيم

المتوفى سـنة: 9V هـ طبعـة دار المعرفة للطباعـة

$$
\text { بييروت. }
$$

تاريخ المدارس الوقفية في المدينـة النبويـة،د.طارق

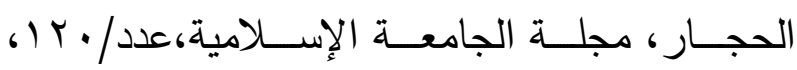
المدينة المنورة، سبك أهـ

تاريخ عجائب الآثار في التراجم والأخبار ، عبد

الرحمن بـن حسن الجبرتي، الناشـر : دار الجيـل ،
بــــــيع الدراسـات والبحـوث التي تهـتم بـالوقف العلمي والتي تبيّن تاريخ الوقف العلمس، والنمـاذج البارزة، وأثره الإيجابي على الفرد و المجتمع. ع__إقامة الندوات والمؤتمرات التي تسهم في تفعيل الوقـف العلمـي، وتوعيـة المجتمع بأهميتهـه وترسيخ مفاهيمه.

○ـ توضيح المجالات العلمية التي يمكن أن يساهم فيهـا الوقـف: مـن خـلال دراسـات أولويـات البحـث العلهي، وتطـوير التعليم، وكذلك أولويـات التوزيـع الجغرافي لإنشاء مؤسسات تعليمية وقفية. 7ـ التعريـف بالمؤسســات العلميــة الإســلاميةة، وبيان دورهـا في المجتمـع، وكيفيـة الوقف عليها.

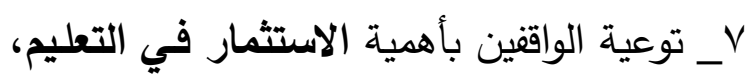
وأثـر ذلـك علــى مؤسســاتهم الاقتصــادية فـي المستقبل.

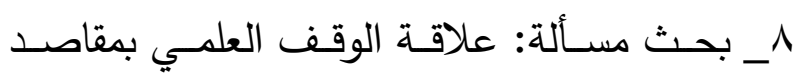
الشريعة.

9_ بحث مسألة: تطبيقات الوقف العلمي في العصر العباسي. • ـ بحـث مسـألة: أثر الوقف العلمي في البنـاء الحضاري.

مَ

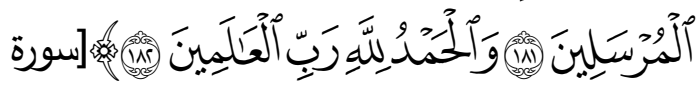
[الصافات] 
دور الوقف في دعم البحـث العلمـي - دراسـة

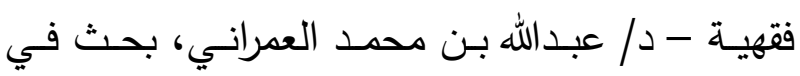
منتدى المشاركة المجتمعية في مجال البحث العلمي، جامعة الإمام، الرياض.

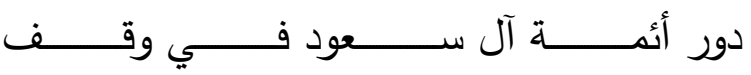
المخطوطات،عبـدالرب محمـــ المنيـف، بحـث غيـر

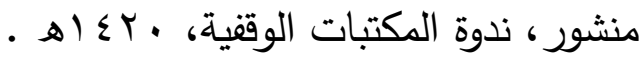
• رحلـة ابـن جبيـر ، "تذكرة بالأخبـار مسن اتفاقـات

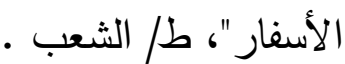
• الرد على البكري :تلخيص كتاب الاستغاثة، أحمد بن عبد الحليم بن تيمية الحراني أبوالعباس،تحقيق : محمد علي عجال، الناشر : مكتبة الغرباء الأثريـة -

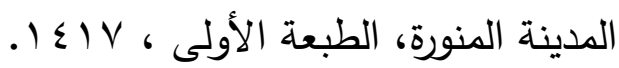
روضـة الناظر وجنـة المناظر ، عبد الله بن أحمد بن قدامة المقدسي أبو محمد، الناشر : جامعة الإمام

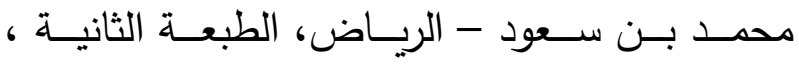
9 \% إ، تحقيق : د. عبد العزيز عبد الرحمن السعيد

الزوايــا والمــدارس العثمانيــة بـالقيروان، لنجـوى عثمان، بحوث المؤتمر الدولي حول العلم والمعرفة فـي العـالم العثــاني، (إســانبول: مركـز الأبحـاث للتاريخ والفنون والثقافة الإسـلامية، سنة . . . بم). • السلوك لمعرفة دول الملوك، المقريزي ، ط/أولى.

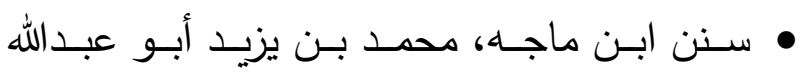
القزويني،الناشـر : دار الفكـر - بيـروت، تحقيـق: محمد فؤاد عبد الباقي.
تحرير ألفاظ التنبيه، النووي، 1 • ـ اهـ تحفة المحتاج، لعمر بن علي بن أحمد الوادياشي الأندلسـي المتوفى سـنة: ؟ ؟ ـ هـ طبعـة: دار حراء مكة المكرمة سنة: 7 ، ـ ا هـ الطبعة: الأولى بتحقيق عبد الله بن سعاف اللحياني. • جامع البيان في تأويل القرآن، محمد بن جرير بن يزيد بن كثير بن غالب الآملي، أبو جعفر الطبري، المحقـق: أحمـد محمـد شــاكر ، الناشـر : مؤسســة الرسالة،الطبعة : الأولى ، • ب أ هـ - ... . م الجامع الصـيح المختصر ، محمد بن إسـاعيل أبو عبدالله البخاري الجعفي، الناشر : دار ابن كثير

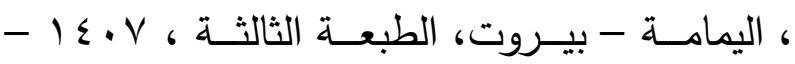
9 AV الجامع الصحيح سنن الترمذي، محمد بن عيسى أبو عيسى الترمذي السلمي،الناشر : دار إحياء التراث

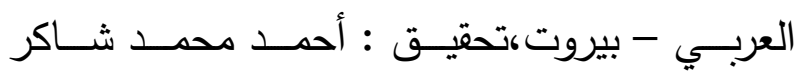
وآخرون. الجـامع لأحكام القرآن، محمد بـن أحمد بن أبي بكر بن فرح القرطبي أبو عبد الله. حاشية ابن عابدين

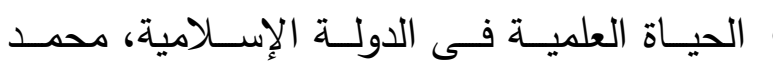
الحسينى عبد العزيز، وكالة المطبوعات الكويت. الدراري المضية شرح الدرر البهية،محمد بن علي الشوكاني،الناشر : دار الجيل - بيروت ، V • ع I - 
• كثـاف القتـاع، لمنصـور بـن يـونس بـن إدريس البهوتي المتوفى سنة: 101 . 1 هـ طبعـة: دار الفكر بيروت.

• كنز العمال في سنن الأقوال والأفعال، علي بن حسام الدين المتقي الهندي،الناشر : مؤسسة الرسالة

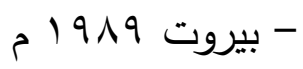

اللباب في الجمع بين السنة والكتاب، محمد علي

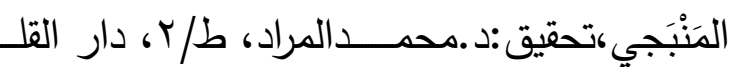

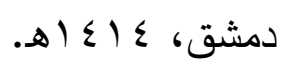

• لسان العرب لأبي الفضل جمال الدين محمد بن مكرم بن منظور الإفريقي المصـري المتوفى سـنة:

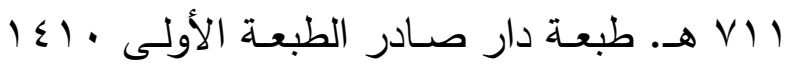

• لمحسات مـن تـاريخ الكتـب والمكتبـات ، د/عبـد

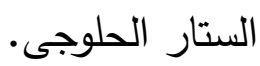

المبسوط لشـش الدين السرخسي المتوفى سـنة: . 9 §ـ. طبعة دار الفكر سنة: 9 . ع 1 هـ. مجمـوع الفتـاوى - ابـن تيميـة، جمـع ابـن قاسـم النجدي، طا الرئاسة . المجمـوع في شـرح المهذب، لأبـي زكريـا محـي الدين بن شرف النووي المتوفى سنة: TV T هـ طبعة

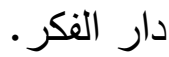

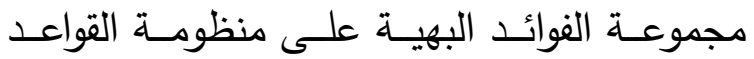
البهية،صـالح بـن محمـد بـن حسـن الأسـمري،اعتنى بإخراجها : متعـب بـن مسـعود الجعيد،دارالصـميعي
سـنن أبــي داود،سـليمان بـن الأثـعث أبـو داود السجستانيالأزدي،الناشــر : دار الفكــر ، تحقيــق : محمد محيي الدين عبد الحميد. السـن الكبـرى وفي ذيلـه الجوهر النقي،أبـو بكر أحمد بن الحسين بن علي البيهقي، مؤلف الجوهر النقي: علاء الدين علي بن عثمان المارديني الشهير بـابن التركماني،الناشـر : مجلـس دائـرة المعـارف النظامية الكائنة في الهند ببلدة حيدر آباد، الطبعة :

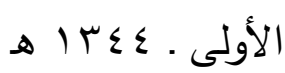
شرح ابن بطال على صحيح البخاري،ط/ ا . شـرح فتح القـدير لكمـال الـدين محمـد بـن عبد الواحد السيواسـي المتوفى سنة: ابح هـ. طبعـة دار الفكر بيروت الطبعة الثانية. شـعب الإيمـان، أبـو بكـر أحمــــــن الحسـين البيهقي،الناشـر : دار الكتـب العلميــة - بيـروت ، الطبعـة الأولـى ، ، إك اتحقيـق : محمـــ السـعيد

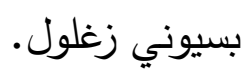

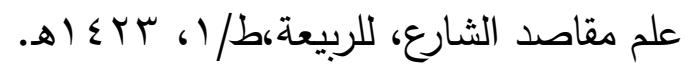
فتح الباري شرح صحيح البخاري، أحمد بن علي بن حجر أبو الفضـل العسقلاني الثـافعي، الناشـر:

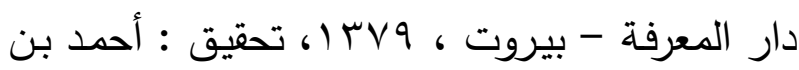
علي بن حجر أبو الفضل العسقلاني الثافعي.

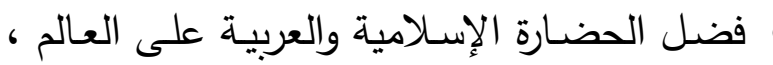
زكريا هاشم زكريا ، دار نهضة مصر . 


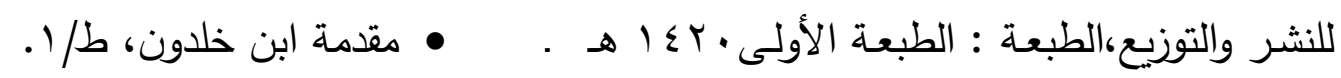

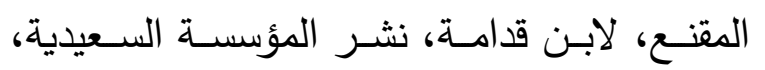

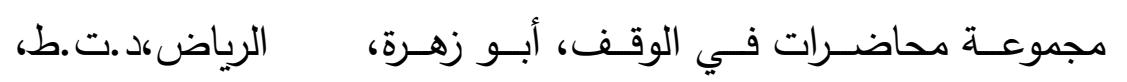

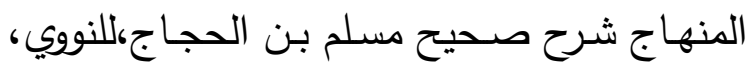

5|9V1

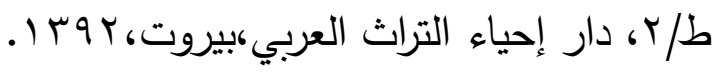
• المحلى للآثار لأبسي محمد علي بـن أحمد بـن

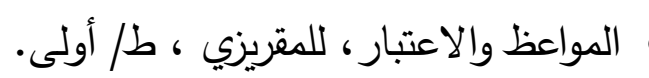

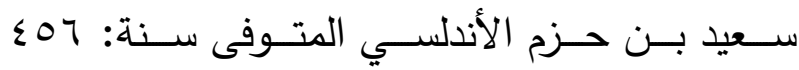
مواهب الجليل لشرح مختصر خليل لأبي عبد الله هـبتحقيق الدكتور عبد الغفار سليمان البنداري طبعة الاندي محمد بن عبد الرحمن المغزبي المعروف بالحطاب • دار الفكر

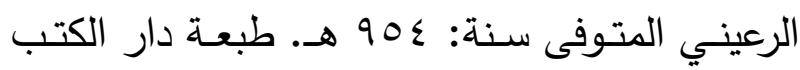

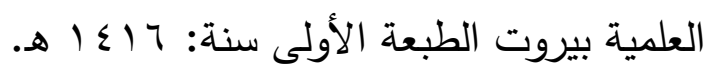
موسوعة الحضارة الإسلامية د/أحمد شلبى.

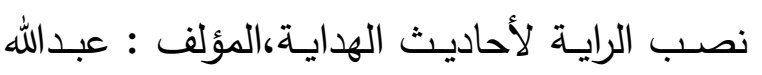
بـن يوسف أبـو محمد الحنفي الزيلعي،الناشـر :دار

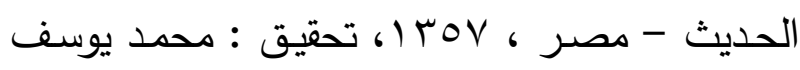

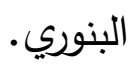

• المدونة الكبرى لإمام مالك بن أنس لسحنون بن

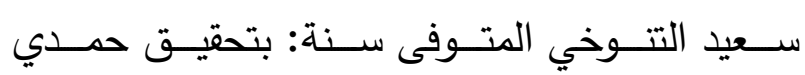
الدمرداش محمد طبعة: مكتبـة نزار مصطفى البـاز

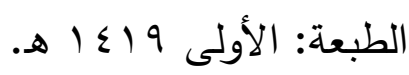

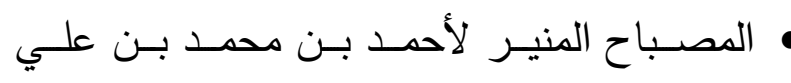

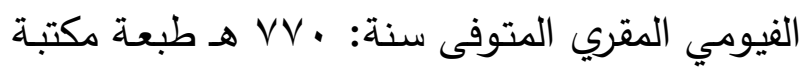

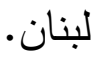

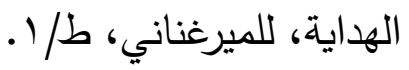
• الوقف الثقافي والعلمي، أهميته وأنواعـه، د/أحمد الهد • معجم البلدان ، يـاقوت الحمـوي ، دار صـادر ،

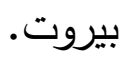

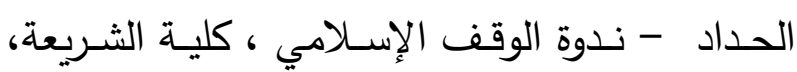
• معجم مقاييس اللغة لابن فارس،ط/ 1. جامعة الإمارات. الوقف وبنية المكتبة العربية - استبطان للموروث الإماث الثقافي، للدكتور / يحيى محمود السـاعاتي ، مركز الملك فيصل للبحوث، الرياض، 1 • ـ أهـ

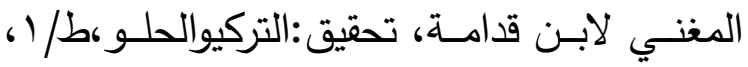
دار هجر، القاهرة،9 •؛ (هـ 


\title{
*The Scientific Endowment is a Sustainable Resource: Applied Juristic Profiles* \\ (A foundational Study presented to Saudi Universities and Scientific Institutions)
}

\author{
DR. Saud Farhan M Alenizi \\ Professor of jurisprudence and its fundamentals at th \\ e University of Northern Borders \\ Head of the Department of Islamic Studies at \\ College of Education and Arts
}

\begin{abstract}
. the search for a financial resource from the fixed assets of universities and all scientific institutions. Most of the world universities went to these resources, which did not require periodic funding from the state budget, and they had their own resources from different endowments such as mines, factories, real estate and agricultural products, and they expanded on projects that generate money based on the huge profits from scientific endowments. In view of the general trend in the privatization of Saudi universities, I have prepared this study to be a foundation and a starting point for all scientific institutions. We will witness a great renaissance, a civilized progress and a scientific and economic strength.

key words: Financial resources - donation - privatization of universities - resources - scientific centers investment - supports the budget - educational institutions.
\end{abstract}

